\title{
Expedition 307 summary ${ }^{1}$
}

\author{
Expedition 307 Scientists $^{2}$
}

\section{Chapter contents}

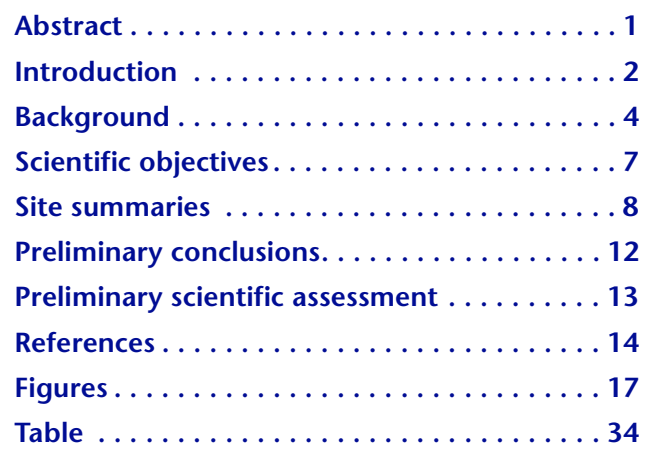

${ }^{1}$ Expedition 307 Scientists, 2006. Expedition 307 summary. In Ferdelman, T.G., Kano, A., Williams, T., Henriet, J.-P., and the Expedition 307 Scientists. Proc. IODP, 307: Washington, DC (Integrated Ocean Drilling Program Management International, Inc.). doi:10.2204/

iodp.proc.307.101.2006

'Expedition 307 Scientists' addresses.

\section{Abstract}

Challenger Mound is a prominent mound structure covered with dead cold-water coral rubble on the southwest Irish continental margin and was the focus of 12 days of scientific drilling aboard the JOIDES Resolution during Integrated Ocean Drilling Program Expedition 307.

Specific drilling objectives included the following:

1. Establish whether the mound roots on a carbonate hardground of microbial origin and whether past geofluid migration events acted as a prime trigger for mound genesis.

2. Define the relationship between mound initiation, mound growth phases, and global oceanographic events.

3. Analyze geochemical and microbiological profiles that define the sequence of microbial communities and geomicrobial reactions throughout the drilled sections.

4. Obtain high-resolution paleoclimatic records from the mound section using a wide range of geochemical and isotopic proxies.

5. Describe the stratigraphic, lithologic, and diagenetic characteristics, including timing of key mound-building phases, for establishing a depositional model of cold-water carbonate mounds and for investigating how they resemble ancient mud mounds.

Two further sites, located down- and upslope of Challenger Mound, completed a transect to (1) constrain the stratigraphic framework of the slope/mound system, (2) identify and correlate erosional surfaces observed in seismic sections, and (3) investigate potential gas accumulation in the sediments underlying the mound.

Drilling revealed that the mound rests on a sharp erosional boundary. Drift sediments below this erosion surface consist of glauconitic and silty sandstone of early-middle Miocene age. The Miocene strata end abruptly in a firmground that is overlain by the late Pliocene-Pleistocene mound succession. The mound flanks are draped by late Pleistocene $(<0.26 \mathrm{Ma})$ silty clay deposits that frequently contain dropstones.

The mound succession mainly consists of floatstone and rudstone formed of fine sediments and cold-water branching corals. Pronounced recurring cycles of several meter scales were recognized in carbonate content and color changes and are most probably associated with Pleistocene glacial-interglacial cycles. A role for hy- 
drocarbon fluid flow in the initial growth phase of Challenger Mound is not obvious either from lithostratigraphy or from initial geochemistry and microbiology results. We found no significant quantities of gas in the mound or in the subbasal mound sediments, nor were carbonate hardgrounds observed at the mound base.

Microbial effects on mound and submound diagenesis are subtle. We detected the methane-sulfate transition only in the Miocene silt and sandstones underlying the mound, where methane concentrations and prokaryotic cell abundances increase with increasing depth. In the mound succession, interstitial water profiles of sulfate, alkalinity, $\mathrm{Mg}$, and Sr suggest a tight coupling between carbonate diagenesis and microbial sulfate reduction. Decomposition of organic matter by sulfate reduction (organoclastic) may drive the biogeochemical processes of mineralogical transformation by (1) producing $\mathrm{CO}_{2}$, which enhances aragonite dissolution and (2) increasing overall dissolved inorganic carbon concentration, which allows (calcium-rich) precipitation. Furthermore, periods of rapid sedimentation overlying hiatuses left distinct signals in the interstitial water chemistry of the Pleistocene sediments that surround and partially bury the mounds of Porcupine Seabight.

\section{Introduction}

The well known warm-water coral reefs developed in shallow-water tropical to subtropical regions with typical carbonate depositional environments. However, the discovery of large-scale deepwater mounds associated with cold-water corals extending along the northeastern Atlantic continental margins raises interesting questions about their structure, origin, and development. Cold-water coral banks from depths where light cannot reach were first described by Teichert (1958) off European coastlines. He drew the attention of geologists to the fact that coral frameworks thrive in high latitudes and/or deep environments and emphasized the similarities with tropical coral reefs. Neuman et al. (1977) discovered that benthic invertebrates including corals and crinoids construct mounds (called lithoherms) several hundred meters wide and $50 \mathrm{~m}$ high at 600-700 meters below sea level (mbsl) along the Straits of Florida. They were considered to be an exceptional case of coral development in deep environments, but contemporaneously similar structures had been recognized in numerous seismic profiles collected from the northeast Atlantic.

Currently, the mounds associated with cold-water azooxanthellate corals are known to occur at depths to $1500 \mathrm{~m}$ along continental margins and shelves of the northeast Atlantic margin from Mauritania to Arctic Norway (Freiwald et al., 2004). Highresolution seismic surveys revealed that the mound structures can reach widths of several kilometers (Henriet et al., 1998; De Mol et al., 2002) and heights of $350 \mathrm{~m}$ (Kenyon et al., 2003). Among the northeast Atlantic, the most intensively studied cold-water coral buildups are located in the Norwegian shelf, Rockall Trough and Porcupine Seabight, southwest of Ireland. Along the Norwegian shelf, extending from $62^{\circ}-71^{\circ} \mathrm{N}$, cold-water corals form reefs up to 30 $\mathrm{m}$ high at 200-400 mbsl. The highest densities and largest continuous reefs occur along the continental shelf break and on the edges of shelf-crossing trenches and morainic formations (Freiwald et al., 2004).

The Porcupine Seabight area surpasses the Norwegian offshore area in terms of size and frequency of cold-water coral buildups. Sixty-six Belgica mounds have been mapped by means of swath bathymetry and two-dimensional (2-D) seismic. In the Hovland mound province, 39 mounds have been identified. In total, 641 Magellan mounds over a total area of $\sim 1500 \mathrm{~km}^{2}$ have been mapped by $2-\mathrm{D}$ and threedimensional (3-D) seismics (Huvenne et al., 2003). This estimation of the mound population is underestimated because the 2-D seismic grid is not dense enough to cover all the mounds in the area. Based on the mound density in this province ( 1 mound/ $\mathrm{km}^{2}$ ), it is estimated that there are at least $1500 \mathrm{Ma}-$ gellan mounds. In total, 1600 mounds could appear in Porcupine Basin. Recently, more mounds have been discovered in the northern mound provinces of Porcupine Seabight, which will significantly increase the total number of mounds in the basin (De Cock, 2005).

The mounds reach heights of up to $250 \mathrm{~m}$ and widths of up to $5 \mathrm{~km}$ and are enclosed by siliciclastic contourites (Van Rooij et al., 2003; Huvenne et al., 2003; De Mol et al., 2002). The mounds in Porcupine Seabight have been the focus of more than 20 cruises in the last decade. Sediments and video images collected on the seafloor indicate that they are commonly colonized by a diverse biota including deepsea corals Lophelia pertusa and Madrepora oculata and other invertebrates (Foubert et al., 2005; Huvenne et al., 2005). Despite this diverse and large data set, knowledge of the internal structure, initiation, and growth of these impressive seafloor features within Porcupine Seabight has remained elusive. Explanations of the origin and evolution of the Porcupine mounds revolve around two scenarios that can be considered as either competing or complementary hypotheses: (1) oceanographic and environmental conditions control mound initiation and growth (e.g., De Mol et al., 2002, 2005a; Huvenne et al., 
2003, 2005), and (2) hydrocarbon seepage initiates microbial-induced carbonate formation and indirectly fuels coral growth (endogenous control) (Hovland et al., 1998; Henriet et al., 2001).

The oceanographic or environmental hypothesis states that the most important condition stimulating mound development is the interaction of hydro- and sediment dynamics. The position and strength of currents provide not only the nutrients for coral and other benthic biota but also clear stable substrates for settlement of coral larvae and inhibit the smothering of coral by too much sediment (Frederiksen et al., 1992 [Faroe Islands]; De Mol et al., 2002 [Porcupine]; Kenyon et al., 2003 [Rockall]; Freiwald et al. 1997 [Norway]; Colman et al., 2005 [Mauritania]). Enhanced bottom currents at tidal frequency (Pingree and Le Cann, 1989, 1990) are observed in the Porcupine mound provinces (Rice et al., 1991; White, 2001). They may result from the internal tides at the boundary between water masses of different densities, such as between Mediterranean Outflow Water (MOW) and Eastern North Atlantic Water (ENAW), located today at $\sim 800$ meters below seafloor (mbsf) (White, 2001). A strong current is thought to provide suspended nutrients to filterfeeding cold-water corals, sweep the polyps clean of detritus, and protect the corals from sediment burial.

Initiation of mound development has been linked to global paleoceanographic change. Closure of the Isthmus of Panama at $\sim 4.6 \mathrm{Ma}$ rerouted the huge warm-water mass of ENAW northward and increased deepwater advection and stratification in the Atlantic (Haug and Tiedemann, 1998). In combination, MOW resumed after the late Miocene-early Pliocene salinity crisis in the Mediterranean (Maldonado and Nelson, 1999). The oldest fossil records of Lophelia and Madrepora were reported from the Mediterranean area in the early Pliocene. Initiation of the cold-water coral mounds thus might have been related to the establishment of MOW and/or ENAW, introducing cold-water coral larvae to the northeast Atlantic (De Mol et al., 2002, 2005a).

The hydrocarbon seepage hypothesis in Porcupine Seabight was first proposed by Hovland et al. (1994). Microbially mediated oxidation of hydrocarbons may provide favorable conditions for cold-water corals by increasing levels of inorganic carbon for skeletal accretion (Hovland et al., 1998) as well as providing a stable substrate for submarine lithification. The linear distributions seen in some mounds of Porcupine Seabight suggests that the mounds were established along linear structures, such as faults (Hovland et al., 1994). A study by Bailey et al. (2003), however, based on two- and three-dimensional seismic data, found no correlation between mound loca- tions and fault lines. Henriet et al. (2001) suggested that conditions in the Magellan mound province during glacial periods were probably suitable for gas hydrate formation and that the decomposition of gas hydrates could trigger a submarine slide. Later phases of gas seepage would then be focused by this buried slide to specific locations, causing the ringlike structure in the Magellan mounds. The oceanographic and fluid seepage scenarios could have acted in a complementary fashion: microbially induced carbonate hardground formation associated with gas or hydrocarbon seepage provided the hard substrate required by the settling coral larvae. Once established, further development of the mound was subject to oceanographic conditions suitable for subsequent coral growth.

The Atlantic cold-water coral mounds have many features in common with numerous Phanerozoic mud mounds. The true dawn of carbonate mud mounds lies in the Cambrian, when mounds suddenly featured diverse microbial and biodetrital fabrics with abundant mound-building calcified microbes (Riding, 1991), calcareous algae, and a variety of Paleozoic benthic invertebrates that may have played an ancillary role in mound construction. In the mid- to late Ordovician, the dramatic rise of large skeletal metazoans such as stromatoporoids, corals (Rugosa and Tabulata), and bryozoans, as well as higher algae, paved the way for the prominent development of reefs and typical stromatactoid mud mounds. Lower Devonian (Gedinnian) mounds in the Montagne Noire, France, exhibit the most spectacular stromatactis fabrics, interpreted as the result of decaying microbial mats (Flajs and Hüssner, 1993). Stratigraphically younger (Emsian) conical carbonate mounds (kess-kess) of the Moroccan AntiAtlas are related to precipitation from hydrothermal fluids (Kaufmann, 1997), some of which are inferred to be related to an isotopically light hydrocarbon source. Some of the most impressive of early Carboniferous bank aggregates, as thick as $1 \mathrm{~km}$, are those known as the Waulsortian reefs (Lees, 1988; Somerville, 2003). In Mesozoic times, declines in the abundance and diversity of microbial mounds are recorded from the Triassic to the Cretaceous. From the mid-Cretaceous onward, microbial fabrics are only known as components of metazoan framework reefs (Riding, 1991). Most Cenozoic mud mounds appear to be of biodetrital origin. Scientific drilling during Ocean Drilling Program (ODP) Leg 182 confirmed the existence of bryozoan reef mounds buried in the cold-water carbonate platform sediments at 200-350 mbsl in Great Australian Bight (Feary et al., 1999; James et al., 2000). These mound complexes consist of unlithified floatstone structures, rich in zooidal bryozoans that were still growing during the last gla- 
cial lowstand. It remains to be determined if the Porcupine mounds are present-day analogs of the Phanerozoic reef mounds and mud mounds, for which depositional processes and environmental settings are not fully understood.

Integrated Ocean Drilling Program (IODP) Expedition 307 was proposed to recover sediment in order to groundtruth the origin and evolution of the coldwater coral mounds in Porcupine Seabight. A wide range of lithostratigraphic, biostratigraphic, magnetostratigraphic, and physical property data will be integrated to evaluate sedimentary processes and paleoceanographic history. The role of microbes in mound initiation and development will be examined by incorporating geochemistry and microbiology. Microbiological profiles will define the sequence of microbial communities and geomicrobial reaction throughout the drilled sections and provide basic information to understand diagenetic processes within the mounds.

Cold-water coral mounds may also be potential high-resolution environmental recorders. Mound section lithology and bioclastic composition might record paleoenvironmental climate changes because cold-water corals are sensitive to conditions such as water temperature, salinity, and current strength. Furthermore, coral skeletons themselves are useful paleoproxy recorders: ${ }^{14} \mathrm{C}$ and $\mathrm{U} / \mathrm{Th}$ ratios have been used to reconstruct changes in deep-sea circulation (Frank et al., 2004) and Cd/Ca ratios to reconstruct nutrient contents (Adkins et al., 1998). Cold-water corals grow as fast as $25 \mathrm{~mm} / \mathrm{y}$ (Rogers, 1999), fast enough to apply the same methods of coral climatology used on tropical-subtropical reef-forming corals. Stable isotope and trace element data are expected to provide environmental constraints.

\section{Background}

\section{Geographic setting}

A geographic overview of Porcupine Seabight and the mound provinces is shown on Figure F1. Three distinct mound provinces have been identified: the Hovland, Magellan, and Belgica mound provinces.

\section{Hovland mounds}

The Hovland mounds are the first mound occurrences reported from industrial data on the northern slope of Porcupine Basin (Hovland et al., 1994) that led to the unveiling of a complex setting with large multiphased contourite deposits and high-energy sediment fills, topped by a set of outcropping mounds or elongated mound clusters as high as 250 m (Henriet et al., 1998; De Mol et al., 2002).

\section{Magellan mounds}

The Hovland mounds are flanked to the north and west by the crescent-shaped, well-delineated Magellan mound province, which is characterized by a very high density of buried medium-sized mounds ( 1 mound $/ \mathrm{km}^{2}$; average height $\left.=60-80 \mathrm{~m}\right)$ (Huvenne et al., 2003). High-resolution seismic data combined with 3-D industrial seismic data (Huvenne et al., 2002) has shed some light on the presence of a past slope failure that partly underlies the mound cluster.

\section{Belgica mounds}

On the eastern margin of Porcupine Basin, a $45 \mathrm{~km}$ long range of large mounds towers from a strongly eroded surface (Fig. F2). The mounds partly root on an enigmatic, deeply incised, very faintly stratified seismic facies (Unit P2) (Fig. F3) (De Mol et al., 2002; Van Rooij et al., 2003) that De Mol (2002) interpreted as a nannofossil ooze of Pliocene age analogous to the similar seismic facies of ODP Site 980 in the southwestern Rockall Trough (Unit P1) (Jansen, Raymo, Blum, et al., 1996) and partly on a layered sequence capped by a set of short-wavelength, sigmoidal depositional units (De Mol et al., 2002, 2005b; Van Rooij et al., 2003).

The Belgica mound province consists of 66 conical mounds (single or in elongated clusters) in water depths ranging from 550 to $1025 \mathrm{~m}$. The mounds are partly enclosed in contourite deposits (Van Rooij et al., 2003). Mounds typically trap sediment on their upslope flank, which is consequently buried, whereas their seaward side is well exposed and forms a steep step in bathymetry. Average slope angles range from $10^{\circ}$ to $33^{\circ}$. The largest mounds have a height of $\sim 170 \mathrm{~m}$. In the deeper part ( $>900 \mathrm{~m}$ water depth) of the Belgica mound province (Beyer et al., 2003), an extremely "lively" mound was discovered in 1998 on the basis of a very diffuse surface acoustic response. This mound, known as Thérèse Mound, was selected as a special target site to study processes involved in mound development for European Union (EU) Fifth Framework research projects. Video imaging revealed that Thérèse Mound, jointly with its closest neighbor, Galway Mound, might be one of the richest cold-water coral environments in Porcupine Seabight, remarkably in the middle of otherwise barren mounds. Challenger Mound, to the southwest, also shares the acoustic properties of Thérèse Mound but is only covered by dead coral rubble (Foubert et al., 2005; De Mol et al., 2005a; Huvenne et al., 2005; Wheeler et al., 2005).

\section{Geologic setting}

Porcupine Seabight forms an inverted triangle opening to the Porcupine Abyssal Plain through a narrow 
gap of $50 \mathrm{~km}$ at a water depth of $2000 \mathrm{~m}$ at its southwest apex between the southern and western tips of the Porcupine Bank and terraced Goban Spur, respectively (Fig. F1). It gradually widens and shoals to depths of $500 \mathrm{~m}$ to the east on the Irish continental shelf and north to Slyne Ridge. Porcupine Seabight is the surface expression of the underlying deep sedimentary Porcupine Basin (Fig. F4), which is a failed rift of the proto-North Atlantic Ocean and is filled with a $10 \mathrm{~km}$ thick series of Mesozoic and Cenozoic sediments (Shannon, 1991). Basin evolution can be summarized in three major steps: a Paleozoic synrift phase, a predominantly Jurassic rifting episode, and a Late Cretaceous-Holocene thermal subsidence period.

\section{Basin development and synrift sedimentation}

The basement of Porcupine Basin is composed of Precambrian and lower Paleozoic metamorphic rocks forming continental crust $\sim 30 \mathrm{~km}$ thick (Johnston et al., 2001). The prerift succession probably commences with Devonian clastic sediments overlain by lower Carboniferous carbonates and clastics. The upper Carboniferous rocks feature deltaic to shallowmarine deposits with Westphalian coal-bearing sandstones and shales and possibly Stephanian redbed sandstones (Shannon, 1991; Moore and Shannon, 1995). Permian and lowermost Mesozoic deposits are early rift valley continental sediments which can be $>2 \mathrm{~km}$ thick. During Permian times, predominantly fluvial and lacustrine sedimentation took place with nonmarine mixed clastic deposits and evaporites. Triassic sediments contain nonmarine to marine facies (Ziegler, 1982; Shannon, 1991). Lower Jurassic deposits are not found over the entire basin but, where present, could comprise limestones and rare organic-rich shales with sandstones.

\section{Jurassic rifting phase}

The middle Kimmerian rifting phase marked an increase in tectonic events in the Arctic, Atlantic, and Tethys rift systems. This major tectonic event was apparently accompanied by a renewed eustatic lowering of sea level and is likely responsible for erosion of a large part of the Triassic and Jurassic deposits (Ziegler, 1982). Middle Jurassic fluvial claystones and minor sandstones might lie unconformably above earlier deposited strata and can be considered to be products of this major rifting episode. During the Late Jurassic, differential subsidence was responsible for the transition from a continental to a shallowmarine sedimentary environment in Porcupine Basin.

\section{Cretaceous subsidence and Paleogene- Neogene sedimentation}

Porcupine Basin began at the start of the Cretaceous as a failed rift structure with a typical steer's head profile (Moore and Shannon, 1991). A major rifting pulse during the Early Cretaceous, associated with the Late Kimmerian orogeny, was accompanied by a significant eustatic sea level fall and gave rise to a regional unconformity that is largely of a submarine nature (Ziegler, 1982; Moore and Shannon, 1995). This undulatory unconformity marks the base of the Cretaceous, where marine strata onlap Jurassic sequences (Shannon, 1991). The onset of the Late Cretaceous was characterized by a further relative sea level rise, featuring offshore sandstone bars, followed by a northward thinning and onlapping outer shelf to slope sequence of pelagic carbonates (chalk). Along the southwestern and southeastern margins of the basin, Moore and Shannon (1995) recognized the presence of biohermal reef buildups. The transition from Late Cretaceous to early Paleocene sedimentation is characterized by a high-amplitude seismic reflector marking the change from carbonate to clastic deposition (Shannon, 1991). Most of the Paleogene postrift sediments are dominantly sandstones and shales, influenced by frequent sea level fluctuations. In general, the Paleocene succession is more mud-dominated, whereas the main coarse clastic input occurred in the middle Eocene to earliest late Eocene (McDonnell and Shannon, 2001). The Paleocene-Eocene is subdivided into five sequences characterized by southerly prograding complex deltaic events overlain by marine transgressive deposits (Naylor and Shannon, 1982; Moore and Shannon, 1995). The controls on the relative rises and falls in sea level are dominantly due to the North Atlantic plate tectonic regime. During the late Paleogene and Neogene, passive uplift of the Norwegian, British, and Irish landmasses was very important in shaping the present-day Atlantic margin. Although the origin of this uplift remains unclear, it probably resulted in enhancement of contour currents, causing local erosion, deposition, and an increased probability of sedimentary slides and slumps. Therefore, overall Oligocene and Miocene sedimentation is characterized by along-slope transport and redepositional processes yielding contourite siltstones and mudstones and hemipelagic-pelagic deep-marine sediments, caused by a combination of differential basin subsidence and regional sea level and paleoclimate changes. The youngest unconformity mapped in Porcupine Basin is correlated with an early Pliocene erosion event in Rockall Basin and is considered to be a nucleation site for present-day cold-water coral mounds (e.g., McDonnell and Shannon, 2001; De Mol et al., 2002; Van Rooij et al., 2003).

\section{Pleistocene and Holocene sedimentation}

Recent sedimentation is mainly pelagic to hemipelagic, although foraminiferal sands (probably reworked) can be found on the upper slope of the east- 
ern continental margin. The main sediment supply zone is probably located on the Irish and Celtic shelves, whereas input from Porcupine Bank seems to be rather limited (Rice et al., 1991). In contrast to the slopes of the Celtic and Armorican margins, which are characterized by a multitude of canyons and deep-sea fans, the east-west-oriented Gollum channels are the only major downslope sediment transfer system located on the southeastern margin of the seabight (Kenyon et al., 1978; Tudhope and Scoffin, 1995), which discharges directly onto the Porcupine Abyssal Plain. Rice et al. (1991) suggest that the present-day channels are inactive. According to Games (2001), the upper slope of northern Porcupine Seabight bears predominantly northsouth-trending plough marks on several levels within the Quaternary sedimentary succession. Smaller plough marks are also observed and interpreted as Quaternary abrasion of the continental shelf caused by floating ice grounding on the seabed. An abundance of pockmarks is also apparent on the seabed in this area (Games, 2001).

\section{Seismic studies/site survey data}

Studies carried out during the past seven years under various EU Fourth and Fifth Framework programs, European Science Foundation programs, UNESCO Training Through Research Program, and various European national programs have gathered substantial information from the area of interest, including box cores, long gravity cores, piston cores, high-resolution seismics (surface and deep towed), side-scan sonar (surface and deep-towed) at various frequencies and elevations over the seabed, surface multibeam coverage, and ultra high resolution swath bathymetry (using a remotely operated vehicle [ROV]) and video mosaicking (using ROV). High-resolution seismic data (penetration $=\sim 350 \mathrm{~m}$; resolution $=1-3 \mathrm{~m}$ ) have been acquired over the Belgica mound province (1125 km of seismic lines over a $1666 \mathrm{~km}^{2}$ area). All drill sites are located on high-quality cross lines. Side-scan sonar data have been acquired at various resolutions and elevations: deep-tow $100 \mathrm{kHz}$ sidescan sonar and $3.5 \mathrm{kHz}$ profiler, resolution $=0.4 \mathrm{~m}$ (95 $\mathrm{km}^{2}$ in the Belgica mound province), high-resolution Makanchi acoustic imaging data, and towed ocean bottom instrument side-scan sonar $(30 \mathrm{kHz})$. A multibeam survey was completed in June 2000 (Polarstern), and the area was covered again by the Irish Seabed Program. The ROV VICTOR (Institut Francais de Recherche pour l'Exploration de la Mer) was employed twice (Atalante and Polarstern) to video survey different mounds in the Begica mound province (Thérèse Mound and a transect from Challenger Mound to Galway Mound). Previous subbottom sampling includes more than 40 gravity and piston cores in the Belgica mound province (penetration = $1.5-29 \mathrm{~m}$ ), numerous box cores, and $\sim 1.5$ tons of television-controlled grab samples.

Three main seismostratigraphic units can be identified in the Belgica mound area separated by two regional discontinuities (Van Rooij et al., 2003) (Fig. F3). The lowermost Unit P1 is characterized by gentle basinward-dipping, continuous parallel strata with moderate to locally high amplitude reflectors. A clinoform pattern formed by a number of superposed sigmoid reflectors is encountered in the upper strata of Unit P1 below and adjacent to Challenger Mound (Fig. F5). These clinoforms are frequently characterized by a high-amplitude top sigmoid reflector. They appear to reflect high-energy slope deposits and have the possibility, based on reversals of signal polarity, to contain traces of gas. An alternative explanation for the phenomenon is a contrast in lithology between the top of the clinoforms and the overlying sediments in combination with the geometry of the unit, which enhances the amplitude of the reflection (De Mol et al., 2005b). This seismic facies is interpreted as migrating drift bodies of Miocene age (Van Rooij et al., 2003; De Mol et al., $2005 b)$. The upper boundary of Unit P1 is an erosional unconformity which strongly incises the underlying strata. Unit P2 is characterized by a nearly transparent acoustic facies on top of the erosional unconformity bounding Units P1 and P2. Only a few sets of continuous, relatively high amplitude reflectors are observed within Unit P2. De Mol (2002) interpreted this seismic facies as a nannofossil ooze of Pliocene age analogous to the similar seismic facies of ODP Site 980 in the southwestern Rockall Trough (Jansen, Raymo, Blum, et al., 1996). The uppermost seismic Unit P3, characterized by slightly upslope migrating wavy parallel reflectors, represents Quaternary drift deposits partly enclosing the mounds. The reflectors of Unit P3 onlap the mound, suggesting that the mounds were already present before deposition of the most recent drift. Scouring and moat features around the mounds suggest that they affect the intensity of the currents and the deposition of the enclosing sediments (De Mol et al., 2002; Van Rooij et al., 2003). Challenger Mound roots on the regional erosional unconformity separating Units P1 and P3 (Figs. F3, F5). The mound appears on seismic profiles as an almost acoustically transparent domeshaped structure. The mound is bounded by diffraction hyperbolae originating at the summit of the mound. Inside the mound, no internal reflectors have been recognized, indicating a uniform facies without any large acoustic impedance differences. The mound acoustic facies might also be interpreted as a loss of seismic energy due to scattering or ab- 
sorption by the rough seabed and internal structure of the mound. However, an important observation is that the reflectors underneath the mounds show reduced amplitudes, although the reflectors have not completely disappeared. This argues for the fact that not all the seismic energy is absorbed or dispersed inside the mound facies (De Mol et al., 2005b). The internal structure of the mounds is derived from the observation of shallow cores (Foubert et al., in press) and seismic velocity analyses (De Mol, 2002). The seismic facies of the coral banks is homogeneous and transparent with an estimated internal velocity of $1850 \pm 50 \mathrm{~m} / \mathrm{s}$ based on velocity pull-ups of singlechannel seismic. This velocity suggests carbonaterich sediment (velocity $=2300 \mathrm{~m} / \mathrm{s}$ ) intermixed with terrigeneous material (velocity $=1700 \mathrm{~m} / \mathrm{s}$ ) as groundtruthed by the surficial sediment samples.

\section{Scientific objectives}

\section{External versus internal controls}

The apparent coincidence between the presence of giant mound clusters and potentially deeper-lying hydrocarbon deposits suggests a possible internal control from mostly transient fluxes of geofluids in deep geological reservoirs to the seabed (Fig. F4). Two-dimensional basin modeling has been used to evaluate the possible link between hydrocarbon leakage and mound growth (Naeth et al., 2005). Industrial seismic lines and six exploration wells were used to calibrate the burial and thermal history using vitrinite reflectance, bottom hole temperatures, and apatite fission track data (Naeth et al., 2005). Modeling results indicate that Jurassic and older source rocks are mature to overmature throughout the basin. Cretaceous strata are immature to mature in the central part of the basin and immature on the flanks. The Tertiary sequence remains immature over the entire basin. Hydrocarbon generation started in Late Cretaceous times for the deepest sequences. Phase separation was modeled to occur during migration at depth ranges between 2000 and $4000 \mathrm{~m}$. Upon phase separation, migration of a free gas phase dominated over that of oil, such that gas is the main migrating fluid in shallower intervals. Migration is mainly buoyancy-driven and vertical. The model predicts a potential focusing of gas migration upslope of the Belgica mounds area, where a pinchout of Cretaceous and Tertiary layers beneath the mound area is observed. Only Aptian and Tertiary deltaic layers direct hydrocarbon flow out of the basin. The reconstruction shows that seeping gas may have been available for methanotrophic bacteria and related formation of hardgrounds since the Miocene. Analysis of very high resolution seismic data below the Belgica mounds highlighted acoustic anomalies within the basal sigmoidal sequences (amplitude, instantaneous frequency, and polarity), possibly related to low quantities of gas.

Mound development may be controlled by microbial communities with automicrite formation playing a key role in stabilization of the steep flanks and lithification of the mound core. On the other hand, oceanographic processes may be more significant. These mounds are located on a margin that throughout the Neogene-Quaternary has repeatedly alternated between glacial and interglacial environments. There is also increasing evidence that active mound provinces also occur in oceanographically unique settings (e.g., De Mol et al., 2002; Van Rooij, 2003, 2004; Huvenne et al., 2003; Rüggeberg et al., 2005; Kenyon et al., 2003; Colman et al., 2005). For example, these mounds cluster in the highest salinity water masses and also bathymetrically coincide with the spread of the oxygen minimum zone along the deep continental margin (De Mol et al., 2002; Freiwald et al., 2004). In Porcupine Seabight, these specific environmental conditions are provided by the northward flow of MOW at intermediate depths $(\sim 700-900 \mathrm{~m})$. Locally, turbulent mixing of water masses with density contrasts stimulate productivity and increase nutrient export, creating conditions favorable for coral growth (e.g., De Mol et al., 2005a). Such observations consequently argue for a complex but important external control. A central hypothesis to be tested is to what extent mound initiation and growth relies on internal versus external processes (Henriet et al., 2002).

\section{Mounds and drifts}

The thick drift sediment sheet enclosing the mounds holds a high-resolution record of past fluctuations of water masses and currents on this section of the North Atlantic margin (Van Rooij, 2004). Correlation of the Porcupine drift record with ODP sites along the Atlantic margin creates the potential for cross-basin comparisons. Corals in the drill cores provide information on paleoceanographic conditions, as already substantiated by pre-IODP coring results (Marion Dufresne preparatory coring) (Foubert et al., 2005). Variations in terrigeneous content and organic matter in drift sediments should allow us to trace terrestrial sources and shelf-to-slope sediment pathways.

\section{Hypotheses tested}

The objectives of Expedition 307 were framed by four major hypotheses:

1. Gas seeps act as a prime trigger for mound genesis: a case for geosphere-biosphere coupling. Drilling to the base of the mounds will allow verification 
of the extent to which fluids may or may not have played a role in mound genesis and/or growth.

2. Mound "events" (prominent erosional surfaces) reflect global oceanographic events. Erosional surfaces are displayed on high-resolution seismic lines. Holes penetrating these unconformities were analyzed by means of high-resolution stratigraphy. The well-established biostratigraphy for the Neogene marine sections of the North Atlantic support interpretations of the timing of the unconformities.

3. The mound may be a high-resolution paleoenvironmental recorder because of its high depositional rate and contents of organic skeletons. A series of well-established proxies can be used to study paleoenvironmental change including response to Pleistocene glacial-interglacial cycles.

4. The Porcupine mounds are present-day analogs for Phanerozoic reef mounds and mud mounds. There are still debates on depositional processes of ancient carbonate mounds that occur ubiquitously in Paleozoic-Mesozoic strata worldwide. The role of microbes in producing and stabilizing sediments has been especially acknowledged by a number of case studies in the last decade; however, conclusive evidence is still missing. Only scientific drilling provides significant information on stratigraphy, depositional age, sediment/faunal compositions, and geochemical/microbial profiles of the mound interior. These data sources together establish the principal depositional model of deepwater carbonate mounds and evaluate the importance of microbial activity in mound development.

\section{Site summaries}

\section{Site U1316}

Site U1316 (proposed Site PORC-4A; $51^{\circ} 22.56^{\prime} \mathrm{N}$, $11^{\circ} 43.81^{\prime} \mathrm{W}$; $965 \mathrm{~m}$ water depth) is located in downslope sediment deposits $\sim 700 \mathrm{~m}$ southwest of Challenger Mound (Figs. F6, F7). The principal objectives at Site U1316 included the following:

- Gain insight into the history of drift deposits on the downslope flank of Challenger Mound and the off-mound transport of mound-related skeletal and nonskeletal grains.

- Investigate the character and age of the clinoforms observed in the upper seismic Unit P1, which appear to form the basement of Challenger Mound.

- Evaluate whether the clinoforms contain high concentrations of gas and thus represent a potential hazard for drilling in Challenger Mound. Fur- ther drilling at Challenger Mound (Site U1317) was contingent on investigation of the sediments along its flank at Site U1316.

Sediments recovered from Site U1316, located basinward of Challenger Mound, contain a suite of post-, syn-, and premound sediments (Figs. F8, F9). The uppermost lithostratigraphic Unit 1 is $52-58 \mathrm{~m}$ thick and is mainly composed of grayish brown silty clay. It is divided into two subunits. Subunit $1 \mathrm{~A}$ is dominated by dark grayish green silty clay, whereas Subunit $1 \mathrm{~B}$ contains very dark gray silty clay interbedded with fine sand layers, interpreted as millimeterand centimeter-scale turbidites. Dropstones are observed throughout Unit 1 in distinct intervals. The base of Unit 1 is defined by an erosive unconformity overlain by a fining-upward sequence of graded fine to very fine sand beds. A $2-4 \mathrm{~m}$ thick coral-bearing facies underlies this erosional boundary and defines lithostratigraphic Unit 2. Corals in the basal layer of this unit exhibit floatstone facies, which could have been buried in their growth position. For the uppermost coral horizon a debris flow transport process is suggested by (1) the high fragmentation of corals compared to the coral-bearing horizons below and (2) the fine-grained matrix-supported texture. The age of Unit 2 is mostly Pleistocene, which corresponds to the age of the thick coral mound at Site U1317. Unit 2 rests on lithostratigraphic Unit 3, with a distinct unconformity surface. Unit 3 consists of $92 \mathrm{~m}$ thick (Hole U1316C) heterogeneous dark green glauconitic siltstone and is calcareous in the lower part. Dolomite precipitation formed lithified layers at $\sim 72$ mbsf.

Calcareous nannofossil data confirm the age of lithostratigraphic Unit 1 as middle-late Pleistocene by the continuous occurrence of Emiliania huxleyi (0.26 Marecent). Coral-bearing Unit 2 ranges in age from late Pliocene to Pleistocene, as defined by the Calcidiscus macintyrei and Pseudoemiliania lacunosa Zones. Planktonic foraminifer data are consistent with these biostratigraphic results. More detailed biostratigraphic study will determine the extent of the unconformity, mound growth, and rapid burial. Lithostratigraphic Unit 3, underlying the unconformity, is early-middle Miocene in age.

Magnetic inclinations for lithostratigraphic Unit 1 average $66^{\circ}$, in the neighborhood of the expected inclination $\left(68^{\circ}\right)$ at the site latitude $\left(51.4^{\circ} \mathrm{N}\right)$; therefore, Unit 1 is normal polarity and is assigned to the Brunhes Chron (0-0.78 Ma). The Brunhes/Matuyama boundary is not observed (Fig. F10). Below the unconformity between Unit 2 and Unit 3, magnetic intensities are weaker (typical for carbonate-rich sediments) and inclination data are more scattered and could not be interpreted in terms of magnetic polar- 
ity stratigraphy. Extended core barrel (XCB) coring disturbance also degraded the paleomagnetic signal in the cores.

Distinct trends and patterns, which could be related to lithology and seismology, were observed in the physical property measurements. Lithostratigraphic Unit 1 has high magnetic susceptibility and natural gamma radiation typical of relatively siliciclastic rich sediment, both of which have lower values in Units 2 and 3, supportive of the observation of increased carbonate content relative to Unit 1 . The downhole increase in density at the Unit $2 / 3$ boundary is the cause of a strong reflection recognized as a regional unconformity in the seismic survey.

After an unsuccessful attempt to log Hole U1316A, triple combination (triple combo) and Formation MicroScanner (FMS)-sonic tool string downhole logs were acquired between 60 and 140 mbsf in Hole U1316C. Density, resistivity, and acoustic velocity logs show a steady downhole increase due to compaction, interrupted by $0.2-5 \mathrm{~m}$ thick intervals of higher values indicating the presence of more lithified layers. Photoelectric effect (PEF) values for these layers indicate that they are carbonate rich. These lithified layers are the cause of several strong reflections in the sigmoidal package in the seismic section at this site.

The interplay of diffusion and burial and microbialmediated reactions dictates the profiles of interstitial water chemical species and dissolved gas chemistry at Site U1316. Li and B are apparently being released at depth during silicate diagenesis, whereas Sr is most likely released during carbonate diagenesis deep in Unit 3 or below. Concave-upward curvature in the profiles of minor elements $\mathrm{Li}, \mathrm{Sr}$, and B suggests that high rates of sediment burial in the uppermost 80 mbsf dominates diffusion. Interstitial water alkalinity, ammonia, and sulfate profiles indicated two zones of microbiological activity: an upper zone of activity between the surface and 10 mbsf and a lower zone between 80 and $100 \mathrm{mbsf}$, the latter driven by methane oxidation. Prokaryotes are present in all samples counted, but abundances appear to be low throughout much of Site U1316 (Fig. F11); a zone nearly $30 \mathrm{~m}$ thick between 56 and 85 mbsf appears to represent a "dead zone" based on the absence of evidence for cell division. However, prokaryote abundances increase in the zone of apparent methane oxidation coupled with sulfate reduction (Fig. F11). Enhanced ethane/methane ratios suggest preferential removal of methane over ethane through the methane-sulfate transition (82-130 mbsf). Generally, methane concentrations are low within Subunit 3A sediments and only increase to concentrations of $2 \mathrm{mM}$ at $130 \mathrm{mbsf}$. We found no significant accumulations of gas within the sediments that coincided with the clinoforms in the seismic survey.

\section{Site U1317}

Site U1317 is located on the northwest shoulder of Challenger Mound (proposed Site PORC-3A; $51^{\circ} 22.8^{\prime} \mathrm{N}, 11^{\circ} 43.1^{\prime} \mathrm{W}$; 781-815 m water depth) (Fig. F7). Scientific drilling of Challenger Mound was the central objective of Expedition 307. Specific objectives of drilling Site U1317 were as follows:

- Establish whether the mound base is on a carbonate hardground of microbial origin and whether past geofluid migration events acted as a prime trigger for mound genesis.

- Define the relationship, if any, between the mound-developing event and global oceanographic events that might have formed the erosional surfaces observed in high-resolution seismic profiles.

- Analyze geochemical and microbiological profiles that define the sequence of microbial communities and geomicrobial reaction throughout the drilled sections.

- Describe stratigraphic, lithologic, and diagenetic characteristics for establishing the principal depositional model of cold-water coral mounds including timing of key mound-building phases.

Sediments from on-mound Site U1317 can be divided into two lithostratigraphic units; an Upper Pliocene-Pleistocene coral-bearing unit (Unit 1) and a Miocene siltstone (Unit 2) (Figs. F8, F9). Unit 1 consists mainly of coral floatstone and rudstone further characterized by repeated cyclic color changes between light gray and dark green. Sediment carbonate contents and coral preservation relate to color: lighter-colored sediments tend to be more calcareous and commonly exhibit lithification textures and dissolved coral fragments. Corals were dominated by the species Lophelia pertusa. The thickness of the unit increases toward the middle of the mound from 130 $\mathrm{m}$ in Hole U1317A to $155 \mathrm{~m}$ in Hole U1317E closest to the mound summit (Figs. F8, F12). The horizontal distance between the two holes is $<100 \mathrm{~m}$. Coral mound Unit 1 rests on a sharp erosional boundary that appears identical to the boundary between Units 2 and 3 at Site U1316 (Fig. F13). The mound base, at the top of Unit 2, is characterized by firmground exhibiting lighter color probably due to submarine alteration. No lithification feature was recognized at the mound base. Unit 2, $124 \mathrm{~m}$ thick (Hole U1317D), consists of glauconitic and partly sandy siltstone, which increases in carbonate content downhole. It is lithostratigraphically correlated with Unit 3 at Site U1316. 
Poor preservation and the exclusion of warm-water taxa made it difficult to construct a high-resolution nannofossil biostratigraphy for the mound sediment. The early Pleistocene age of the small Gephyrocapsa Zone (0.96-1.22 Ma) is assigned for the upper part of Unit 1 (0-73.0 mbsf in Hole U1316A) by the high abundance of small Gephyrocapsa. This age assignment is considered tentative as the small Gephyrocapsa Zone is only well preserved in sediment from 0 to 11 mbsf. Alternatively, the presence of $P$. lacunosa $(\mathrm{LO}=0.46 \mathrm{Ma})$ and the absence of $C$. macintyrei $(\mathrm{LO}=1.59 \mathrm{Ma})$ indicate that age of the upper part of Unit 1 is between at least 0.46 and $1.59 \mathrm{Ma}$. The middle-late Pleistocene age of Subzone Pt1b (0-0.65 $\mathrm{Ma}$ ) is assigned based on planktonic foraminifer biostratigraphy for the upper part of Unit 1 (0-63 mbsf). Further investigation is needed to determine if the sediment, and subsequent nannofossil age assignment, of the upper part of Unit 1 (0-11 mbsf) is reworked or in place. Nannofossils from the lower part of Unit 1 (82.7-130.1 mbsf) correspond to the early Pleistocene C. macintyrei Zone (1.59-1.95 Ma). A Pliocene-Pleistocene age is assigned for the lower part of Unit 1 based on planktonic foraminifers. The age of Unit 2 ranges from early-middle Miocene to possibly early Pliocene, as indicated by nannofossils, and is interpreted from planktonic foraminifers as Miocene. The interval of the hiatus between Units 1 and 2 has a lower limit of 13.5 m.y., as indicated by nannofossil datums.

Whole-round cores were measured for magnetization after 0,10 , and $15 \mathrm{mT}$ demagnetization steps. Whole rounds were used because

- Three of the holes would not be opened during the expedition,

- Twice as much sediment (compared to the archive half) would give a better signal in these weakly magnetic carbonate-rich sediments,

- The sediment would be undisturbed by splitting, and

- The possible presence of ephemeral magnetic minerals such as greigite could affect results.

Demagnetization tests were run to ensure that only the overprint was removed by bulk demagnetization at $15 \mathrm{mT}$. Lithostratigraphic Unit 1, the mound sediments, had somewhat scattered inclinations; nevertheless, coherent changes in polarity are observed. Hole $1317 \mathrm{~B}, 0-62 \mathrm{mbsf}$, is predominantly of normal polarity and interpreted as the Brunhes Chron (0$0.78 \mathrm{Ma}$ ) (Fig. F10), and two predominantly reversed polarity intervals occur between 62 and 82 mbsf and 96 and 105 mbsf that are tentatively interpreted as part of the Matuyama Chron. The lower part of Unit 1 below 105 mbsf shows normal polarity, which might correspond to the Olduvai Chron (Fig. F10).
The two lithostratigraphic units at this site exhibit distinctive and contrasting physical properties. In Unit 1, the mound facies, generally low values of natural gamma radiation and magnetic susceptibility are caused by high carbonate content. Some cyclically recurring intervals are characterized by relatively higher natural gamma radiation and magnetic susceptibility, density, and $P$-wave velocity, indicating a higher clay content (Fig. F12). These intervals could be traced from Hole U1317A upslope through Holes U1317B, U1317C, and U1317E. These intervals coincide with dark green floatstones. Despite this layering observed in the cores, the seismic facies throughout the mound appears acoustically transparent in seismic surveys. Transparency could be caused by the high coral content scattering the seismic waves, irregular surfaces, or low acoustic impedance contrasts between lithologic layers. The lower boundary of Unit 1, the mound base, is characterized by an increase in density, gamma radiation, and magnetic susceptibility. Lithostratigraphic Unit 2 is characterized by very low susceptibility values and eight peaks of high density, $P$-wave velocity, magnetic susceptibility, and gamma radiation that coincide with more lithified layers and sandier layers.

Triple combo and FMS-sonic tool string downhole logs and a zero-offset vertical seismic profile were run between 80 and 245 mbsf in Hole U1317D. Density, resistivity, and acoustic velocity logs show steady downhole increases due to compaction interrupted by $0.2-5 \mathrm{~m}$ thick intervals of higher values, indicating the presence of more lithified layers similar to Hole U1316C. PEF values for these layers indicate that they are carbonate rich. These lithified layers are the cause of the high-amplitude sigmoidal reflectors observed in seismic profiles (in lithostratigraphic Unit 1 and seismic Unit P1) and that are correlated with the aforementioned peaks in physical property measurements. Interval velocities were calculated from the check shot survey. They confirm the values of the acoustic velocity logs but show that the shipboard $P$-wave velocity measurements made on the cores significantly underestimate in situ velocity (Fig. F14). Prior to drilling, the possibility of a mound velocity of $1850 \mathrm{~m} / \mathrm{s}$ could be interpreted as partial lithification as the result of biogeochemical processes. Figure F14 shows the mound is, in fact, mostly composed of unlithified sediments with modest velocities.

A role for hydrocarbon fluid flow in the initial growth phase of Challenger Mound is not obvious from either lithostratigraphy or the initial geochemistry and microbiology results. We found no significant quantities of gas in the mound or in the subbasal mound sediments, nor were carbonate 
hardgrounds observed at the mound base. Overall indexes of microbial abundance in the mound were low (Fig. F11). In short, Challenger Mound is not a model for a fully microbial origin of Phanerozoic carbonate mounds. Rather, mound geochemistry reflects the interplay of sediment trapping and deposition, mineral-controlled diagenesis, and reactions driven by microbial activities. Methane, sulfate, and alkalinity profiles reflect zones of microbially mediated organic mineralization. The concave-downward profiles for sulfate and the convex-upward curvatures for alkalinity between 0 and 50 mbsf indicate active sulfate reduction. Magnesium also shows a loss, as evidenced in the decreased $\mathrm{Mg} / \mathrm{Ca}$ ratio at these depths (Fig. F15). With the distinct increase in $\mathrm{Sr}$ in this interval, we propose that aragonite dissolution is releasing $\mathrm{Sr}$ to the interstitial pore fluids. Concurrently, dolomite or some other Mg-bearing carbonate mineral (calcian dolomite) is precipitating and removing $\mathrm{Mg}$. Below the mound base, the methane and sulfate profiles between 150 and $200 \mathrm{mbsf}$ define the zone of anaerobic oxidation of methane coupled to sulfate reduction (Fig. F15). Increasing Ca and decreasing $\mathrm{Mg}$ suggest that dolomite is forming within these deeper Miocene sediments.

\section{Site U1318}

Site U1318 (proposed Site PORC-2A; $51^{\circ} 26.16^{\prime} \mathrm{N}$, $11^{\circ} 33.0^{\prime} \mathrm{W} ; 423 \mathrm{~m}$ water depth) is located on the eastern slope of Porcupine Seabight on the southwest continental margin of Ireland (Figs. F1, F6, F9) and is upslope from the Belgica mound province, including Challenger Mound. The principal objective at Site U1318 was to recover sediments from the three seismic units (P1-P3) of the southern Belgica mound province (Fig. F3). Complete data from the seismically low-amplitude layer (Unit P2) would refine the paleoenvironmental history of when Challenger Mound growth initiated.

Sediments from Site U1318 were divided into three lithostratigraphic units based on sediment color, erosional surfaces, and biostratigraphy (Figs. F8, F9). Unit 1 is $78.9-82.0 \mathrm{~m}$ thick and consists of grayish brown silty clay with black mottled structure. This unit was divided into three subunits (1A, 1B, and $1 \mathrm{C})$ on the basis of relative dominance of laminated or bioturbated textures. Dropstones are common in Subunit $1 \mathrm{~A}$, and the base of Subunit $1 \mathrm{C}$ is defined by a sharp erosional boundary.

Unit 2 (4-6 m thick) mainly consists of olive-gray medium-fine sand interbedded with dark yellowish brown silty clay. The sand beds are normal graded with sharp lower and upper boundaries. Pebble-sized clasts, with diameters up to $3 \mathrm{~cm}$, are found in both sand and clay horizons. The base of this unit is a 5-
$10 \mathrm{~cm}$ thick conglomerate that shows normal grading and contains black apatite nodules and was interpreted as a basal conglomerate on an unconformable boundary with Unit 3 .

The top of Unit 3 (84.2-86.7 mbsf) is marked by a $10-20 \mathrm{~cm}$ thick phosphatic shell bed (bivalves), and shells are common in the uppermost $20 \mathrm{~m}$ of Unit 3. Unit 3 is $155 \mathrm{~m}$ thick (Hole U1318B), mainly siltstone, and is divided into three subunits. Subunit 3A is characterized by frequent intercalation of sandstone and is differentiated from darker-colored Subunit 3B, which rarely contains sandy layers. The boundary between Subunits $3 \mathrm{~A}$ and $3 \mathrm{~B}$ is marked by a distinct erosional surface. The boundary between seismic Units P2 and P1 is roughly correlated to the boundary between lithostratigraphic Subunits 3B and $3 \mathrm{C}$, where no evident unconformity was found (Fig. F9).

Unit 1 is younger than $0.26 \mathrm{Ma}$, as indicated by the abundant occurrence of E. huxleyi, and correlates to Unit 1 at Site U1316. Nannofossils from Unit 2 indicate the early Pleistocene small Gephyrocapsa Zone (0.96-1.22 Ma). The interval of the hiatus between Units 1 and 2 was estimated as at least $0.7 \mathrm{~m}$.y. The age of Subunit 3A is older than 3.6 Ma and nannofossil data indicate a clear hiatus between Units 2 and 3 of at least 2.4 m.y. Nannofossil data also indicates that Subunits $3 \mathrm{~B}$ and $3 \mathrm{C}$ are middle to lower Miocene in age (13.6-15.6 Ma).

Magnetic inclinations for lithostratigraphic Unit 1 are close to the expected inclination $\left(68^{\circ}\right)$ at the site latitude $\left(51.4^{\circ} \mathrm{N}\right)$; therefore, Unit 1 is assigned to the Brunhes Chron (0-0.78 Ma). The normal polarity of Unit 1 is truncated by a hiatus, identified by lithostratigraphy and biostratigraphy, so the base of the Brunhes is not represented (Fig. F11). Below the hiatus in lithostratigraphic Unit 3, due to weakened magnetic susceptibilities and intensities, inclination data are more scattered and could not be interpreted in terms of magnetic polarity stratigraphy. It is noteworthy that, although the silty clay sediments are calcareous, carbonate content is not high enough to dilute magnetic susceptibility to the extent observed. Therefore, either lithostratigraphic Unit 3 has a much lower siliciclastic content than is supposed or the magnetic minerals in the unit have been dissolved.

Major changes in physical properties that can be directly related to reflectors in the seismic section were observed at lithostratigraphic unit boundaries. The sand layers, silty clays, and dropstones of lithostratigraphic Unit 2 and the bivalve bed of Unit 3 create a high-amplitude reflector in the seismic profile, and this erosive reflector has been tentatively identified as the upslope continuation of the mound base re- 
flector. The enigmatic low-amplitude seismic package (P2 in Fig. F3), the identification of which was one of the main aims of drilling this site, corresponds to homogeneous calcareous silty clays. Lithostratigraphic Subunit 3C, below 192 mbsf, is characterized by a slight general increase in density in combination with some high-density thin beds and corresponds to high-amplitude, high-frequency parallel reflectors that can be traced along the seismic profile to the sigmoid unit at Site U1316.

Triple combo and FMS-sonic tool string downhole logs were acquired between 70 and 240 mbsf in Hole U1318B. The downhole logs are characterized by low-amplitude variations in lithostratigraphic Subunits 3A and 3B (92-192 mbsf) and by increased velocity and thin lithified layers in Subunit 3C (below 192 mbsf). The hiatus represented by the bivalve bed at the top of Unit 3 is rich in uranium (as seen in the natural gamma radiation logs), which is known to accumulate at hiatuses and condensed intervals.

Periods of rapid sedimentation overlying hiatuses have profoundly affected the chemistry and microbial activity of the Site U1318 sediments. The dominance of burial over diffusion within the upper Unit 1 sediments is strikingly shown by the near-seawater concentrations of $\mathrm{Li}$ and $\mathrm{Sr}$ in the upper $50 \mathrm{~m}$ of drift sediments. Below 50 mbsf both elements linearly increase with depth indicating a source for both elements deeper than our maximum sampling depth. Chlorinity, as meticulously measured by high-precision hand titration, exhibits a constant concentration of $570 \mathrm{mM}$ in Unit 1 . However, we observed a distinct increase in chloride concentrations between 80 and 150 mbsf of as much as $580 \mathrm{mM}$ (at 140 mbsf). This excursion may be correlated to a major oceanographic change in seawater salinity. Buried and repeating trends in the classic sequence of microbially mediated terminal electron acceptor processes of Mn reduction and Fe reduction, followed by sulfate reduction, are manifested in the interstitial water profiles of $\mathrm{Mn}, \mathrm{Fe}$, and sulfate. We observe a peak in dissolved Mn underlain by peaks in Fe and a decrease in sulfate concentrations. This sequence occurs at the surface and repeats at 80 and 180 mbsf. These may be interpreted as buried redox fronts. Prokaryote abundances (Fig. F10) are greater than predicted from the global depth-abundance curve in the sediments of Subunits $1 \mathrm{~B}$ and $1 \mathrm{C}$ but drop precipitously below the hiatus in Unit 2. Deep dolomitization appears be occurring based on the decrease in $\mathrm{Mg}$ at depths below 200 mbsf. This is consistent with microscopic and X-ray diffraction identification of dolomite in these sediments. Si exhibits striking change in the interstitial water concentrations between Unit $1(200 \mu \mathrm{M})$ and Unit $3(900 \mu \mathrm{M})$ sedi- ments. This probably reflects a change in siliceous facies occurring over the hiatus at 82 mbsf. Total carbonate concentrations also change dramatically at this boundary, increasing from $10 \mathrm{wt} \%$ in Unit 1 to a peak of $40 \mathrm{wt} \%$ throughout Subunit 3A.

\section{Preliminary conclusions}

Preliminary conclusions and observations can be framed within the set of hypotheses generated prior to the expedition.

1. Gas seeps act as a prime trigger for mound genesis: a case for geosphere-biosphere coupling.

Drilling to the base of Challenger Mound and deeper suggested that geofluid (i.e., hydrocarbons) did not play a major role in mound genesis and growth. A role for hydrocarbon fluid flow in the initial growth phase of Challenger Mound is not obvious from either lithostratigraphy nor the initial geochemistry and microbiology results. We found no significant quantities of gas in the mound or in the subbasal mound sediments, nor were carbonate hardgrounds observed at the mound base. The mound rests on a Miocene firmground whose origin appears to be an erosional unconformity. The mechanism for the initiation of mound growth (i.e., colonization by corals) awaits closer examination and analysis of the core sections containing the mound base boundary at Sites U1316 and U1317.

2. Prominent erosional surfaces reflect global oceanographic events.

Holes penetrating erosional unconformities at all three sites were drilled and the lithology was linked to the interpreted seismic facies (Fig. F8). An important erosional surface is the late Miocene/Pliocene hiatus, which correlates to the firmground under the mound itself at Site U1317, the unconformity under the coral-bearing Unit 2 at Site U1316, and the phosphorite/bivalve bed hiatus at the top of Unit 3 at Site U1318. Development of phosphorite nodules on a fine sand basement is suggestive of an upwelling regime. Linkage of the seismic stratigraphy and the core lithology at Site U1318, particularly in Subunits $3 \mathrm{~A}$ and $3 \mathrm{~B}$, will provide key information on sediments that have eroded at the deeper Sites U1317 and U1316. We expect that we will be able to link all of the sites from Porcupine Seabight with biostratigraphy from Neogene marine sections from other Deep Sea Drilling Project, ODP, and IODP sites of the eastern North Atlantic. This will support interpretations of the timing of the unconformities.

3. The mound may be a high-resolution paleoenvironmental recorder because of its high depositional rate and abundance of micro- and macrofossils. 
The mound is composed of at least 10 distinct layers of cold-water corals (L. pertusa), clay, and coccoliths down to its base at 130-155 mbsf. These represent intervals of mound development. The identified growth intervals therefore most probably correspond to Pleistocene environmental changes. A series of well-established proxies will be used to study paleoenvironmental change including response to Pleistocene glacial-interglacial cycles. Challenger Mound is also partially buried in drift deposits that contain indications of rapid deposition rates (based on interstitial water chemistry) and evidence for change on glacial-interglacial time periods (distinct intervals of dropstone occurrence).

\section{The Porcupine mounds are present-day analogs for Phanerozoic reef mounds and mud mounds.}

There are still debates on the depositional processes that formed ancient carbonate mud mounds that occur ubiquitously in Paleozoic-Mesozoic strata worldwide. Nevertheless, it is clear that Challenger Mound is not a present-day analog for microbially formed Paleozoic-Mesozoic mounds. Rather, Challenger Mound is in many ways more reminiscent of the Cenozoic bryozoan mounds located at the shelf edge margin of Great Australian Bight (James et al., 2000). A significant difference from Great Australian Bight mounds, however, is the preservation of carbonate mound or reef structures in an essentially siliciclastic environment. The mound section shows little evidence of microbial automicrite, which has been suggested for many ancient mud mounds. The prokaryote abundances in the deeper Miocene sediments are actually significantly greater than in the overlying Pleistocene sediments and relative to the global coverage for this depth. The process that maintains the conical mound geometry with steep flanks is probably related to the sediment-trapping ability and structural network of branching colonies of L. pertusa. The presence/absence of coral frameworks is the key feature to answer this question and will be approached by assessing the 3-D distribution of corals using computerized tomography (CT) scanning (Fig. F16).

Microbial effects on mound and submound diagenesis may play a subtle role in degrading and stabilizing carbonate fractions both within the mound and within the deeper and older Miocene silty clays. Sulfate and alkalinity profiles in the mound reflect zones of microbially mediated organic mineralization through sulfate reduction between 0 and 50 mbsf. Magnesium also shows a loss, as is evident in the decreased $\mathrm{Mg} / \mathrm{Ca}$ ratio at these depths (Fig. F15). With the distinct increase in $\mathrm{Sr}$ in this interval, we propose that aragonite dissolution is releasing $\mathrm{Sr}$ to the interstitial pore fluids. Concurrently, dolomite or some other $\mathrm{Ca}-\mathrm{Mg}$ carbonate mineral (e.g., low-Mg calcite, calcian dolomite, or dolomite) is precipitating and removing $\mathrm{Mg}$. Decomposition of organic matter by sulfate reduction (organoclastic) may be driving this process by (1) producing $\mathrm{CO}_{2}$, which enhances aragonite dissolution, and (2) increasing the overall dissolved inorganic carbon concentration. The absence of dissolved sulfide further suggests that the sulfide produced through microbial sulfate reduction may react with detrital iron minerals and be precipitated as iron sulfide minerals, principally pyrite. The reduction of ferric iron and precipitation of pyrite drives carbonate alkalinity and $\mathrm{pH}$ up and favors carbonate precipitation.

These reactions may be described by the following overall equation:

$$
\begin{gathered}
3 \mathrm{SO}_{4}{ }^{2-}+6 \mathrm{H}_{2} \mathrm{O}+2 \mathrm{FeOOH}+\mathrm{Ca}^{2+}+2 \mathrm{Mg}^{2+}+\mathrm{CaCO}_{3} \rightarrow \\
\mathrm{FeS}_{2}+\mathrm{FeS}+4 \mathrm{Ca}_{0.5} \mathrm{Mg}_{0.5} \mathrm{CO}_{3}+3 \mathrm{CO}_{2}+7 \mathrm{H}_{2} \mathrm{O} .
\end{gathered}
$$

Lower sulfate, $\mathrm{Ca}$, and $\mathrm{Mg}$ and higher alkalinity and Sr concentrations in Hole U1317E suggest that microbially mediated organic mineralization is more intense at the mound top (Fig. F15), where sediments remain in situ, relative to the mound flanks penetrated in Holes U1317A through U1317D, where the sediment is more likely to have been transported downslope.

\section{Preliminary scientific assessment}

Expedition 307 successfully completed and surpassed the operations plan set out in the Expedition 307 Scientific Prospectus. Drilling at all three planned sites reached target depths, sediment upper sections were double- to quadruple-cored with the advanced piston corer (APC), and each site was wireline logged. We now have the core material that, with postcruise analysis, will be used to meet the expedition objectives and confirm or disprove many hypotheses about carbonate mound initiation and growth.

Challenger Mound is one of thousands of mound structures in Porcupine Seabight and is the first of these to be cored deeper than $12 \mathrm{~m}$, so coring this structure was a true exploration. Already many results are clear, as detailed elsewhere in this report. The mound is composed of cold-water coral fragments (L. pertusa), clay, and coccoliths down to its base at 130-155 mbsf, and at least 10 distinct layers-active growth intervals of the coral mound-are evident in lithology and physical properties. Sea bottom temperature in Porcupine Seabight during the last glacial period was too cold for $L$. pertusa, suggesting that the growth intervals most probably correspond to Pleistocene interglacials. Much of the late 
Pleistocene material is absent from the top of the mound, while at the same time siliciclastic sediment is building up in drifts both upslope and downslope; the mound is slowly being buried. By positioning holes along an upslope transect across the mound site (U1317), we have exposed a short stratigraphic cross section that will be useful for reconstructing the growth of Challenger Mound and similar structures.

The theory that this mound is built from carbonate precipitated by microbes fed by methane seeps has been disproved, although the role of prokaryotes in both carbonate dissolution and secondary cementation reactions may be important. The lithology and age of the enigmatic sedimentary packages that underlie the mound, known previously only from seismic lines, have been identified. The mound is rooted on an erosional unconformity that was identified at all three sites, and a thick early-middle Miocene package of green-gray calcareous siltstones lie beneath the mound.

The expedition was planned for only 10 days of science operations with a short transit from Dublin, Ireland, to the sites, which left little room for technical delays. We were fortunate to have mild sea conditions; no time was lost to weather, which is certainly not guaranteed west of Ireland in early May. We also made full use of the extra 2 days of operations that resulted from the early departure from Dublin at the start of the expedition.

The holes were originally planned to be cored with the APC to refusal and then deepened to target depth with XCB. However, we found in the first hole at Site U1316 that the deeper sediments were more lithified than expected; thus XCB coring was frustratingly slow. We therefore decided to core these sediments using rotary core barrel (RCB), which proved to be faster (penetration rate $=6.3 \mathrm{~m} / \mathrm{h}$ compared to $2.7 \mathrm{~m} / \mathrm{h}$ ), had similar recovery (average = $80 \%$ ), caused less biscuiting than XCB coring, and provided cores more suitable for geochemistry, microbiology, and fine-scale stratigraphy (Table T1).

Downhole logging initially proved to be a challenge in these relatively shallow holes. For the first logging attempt in Hole U1316A, we set the pipe at the optimistically shallow depth of $30 \mathrm{mbsf}$ to maximize the logged interval, but the sediment at this depth was too soft to retain integrity and the logging tools were blocked from passing downhole. However, the three subsequent downhole logging operations were successful, with all logging tools reaching total depth, including the check shot survey at Site U1317.

The expedition employed an integrated sedimentological/geochemical/microbiological approach. Each laboratory group was aware of the value of their analyses to the other groups and the connections between, for example, microbial action, interstitial water chemistry, and diagenetic alteration of the sediments. There was, therefore, support for the extensive microbiological sampling-even when 1.5 $\mathrm{m}$ sections were assigned and disappeared from the core receiving area to the hold for sampling for deoxyribonucleic acid (DNA), lipids, cell enumeration, and experimental work. Additionally, this expedition was the first to operate the Fast Track multisensor core logger (MSCL) without problems for all cores, including the sections sampled for microbiology.

In the core laboratory, a new technique was developed for splitting cores that contain coral in an unlithified matrix. Conventional methods of core splitting using wire and saw can result in coral fragmentation and pieces being dragged down the split core surface, destroying the sediment structure. To avoid this undesirable outcome, all core sections from Hole U1317C were split by saw after being frozen to $-50^{\circ} \mathrm{C}$ (Fig. F17). Some short freeze-cracks in the split core face were apparent, but the coral structure was preserved and it was generally agreed that this method produced superior results compared to conventional methods. Cores from Holes U1317A and U1317D were split by saw in the normal way so that the sedimentologists could describe at least one full stratigraphic section immediately; Holes U1317B and U1317E remained unopened for potential whole-round CT scanning and splitting while frozen at the IODP Gulf Coast Core Repository, College Station, Texas (USA).

\section{References}

Adkins, J.F., Cheng, H., Boyle, E.A., Druffel, E.R.M., and Edwards, R.L., 1998. Deep-sea coral evidence for rapid change in ventilation of the deep north Atlantic 15,400 years ago. Science, 280:725-728. doi:10.1126/science.280.5364.725

Bailey, W., Shannon, P.M., Walsh, J.J., and Unnithan, V., 2003. The spatial distributions of faults and deep sea carbonate mounds in the Porcupine Basin, offshore Ireland. Mar. Pet. Geol., 20(5):509-522. doi:10.1016/ S0264-8172(03)00079-5

Beyer, A., Schenke, H.W., Klenke, M., and Niederjasper, F., 2003. High resolution bathymetry of the eastern slope of the Porcupine Seabight. Mar. Geol., 198:27-54. doi:10.1016/S0025-3227(03)00093-8

Colman, J.G., Gordon, D.M., Lane, A.P., Forde, M.J., and Fitzpatrick, J.J., 2005. Carbonate mounds off Mauritania, North-West Africa: status of deep-water corals and implications for management of fishing and oil exploration activities. In Freiwald, A., and Roberts, M. (Eds.), Cold-Water Corals and Ecosystems: New York (SpringerVerlag), 417-441. 
De Cock, K., 2005. 3D-seismiche studie van koralbaanken aan de oostelijke rand van het Porcupine bekken [M.S. thesis]. Ghent Univ., Belgium.

De Mol, B., 2002. Development of coral banks in Porcupine Seabight (SW Ireland): a multidisciplinary approach [Ph.D. dissert.]. Ghent Univ., Belgium.

De Mol, B., Henriet, J.-P., and Canals, M., 2005a. Development of coral banks in Porcupine Seabight: do they have Mediterannean ancestors? In Freiwald, A., and Roberts, M. (Eds.), Cold-Water Corals and Ecosystems, Heidelberg (Springer-Verlag), 513-533.

De Mol, B., Kozachenko, M., Wheeler, A., Alvares, H., Henriet, J.-P., and Olu-Le Roy, K., 2005b. Thérèse Mound: a case study of coral bank development in the Belgica mound province, Porcupine Seabight. Int. J. Earth Sci. doi:10.1007/s00531-005-0496-X

De Mol, B., Van Rensbergen, P., Pillen, S., Van Herreweghe, K., Van Rooij, D., McDonnell, A., Huvenne, V., Ivanov, M., Swennen, R., and Henriet, J.-P., 2002. Large deepwater coral banks in the Porcupine Basin, southwest of Ireland. Mar. Geol., 188(1-2):193-231. doi:10.1016/ S0025-3227(02)00281-5

Feary, D., Hine, A., Malone, M., and the Leg 182 Scientific Party, 1999. Cool-water 'reefs,' possible hydrogen sulphide/methane clathrates, and brine circulation-preliminary results of Leg 182 drilling in the Great Australian Bight. JOIDES J., 25(2):4-7.

Flajs, G., and Hüssner, H., 1993. A microbial model for the lower Devonian stromatactis mud mounds of the Montagne Noire (France). Facies, 29:179-193.

Foubert, A., Beck, T., Wheeler, A.J., Opderbecke, J., Grehan, A., Klages, M., Thiede, J., Henriet, J.-P., and the Polarstern ARK-XIX/3A Shipboard Party, 2005. New view of the Belgica mounds, Porcupine Seabight, NE Atlantic: preliminary results from the Polarstern ARKXIX/3a ROV cruise. In Freiwald, A., and Roberts, M. (Eds.), ColdWater Corals and Ecosystems: Heidelberg (Springer-Verlag), 403-415.

Frank, N., Paterne, M., Ayliffe, L., van Weering, T., Henriet, J.-P., and Blamart, D., 2004. Eastern North Atlantic deep-sea corals: tracing upper intermediate water $\delta^{14} \mathrm{C}$ during the Holocene. Earth Planet. Sci. Lett., 219:297309. doi:10.1016/S0012-821X(03)00721-0

Frederiksen, R., Jensen, A., and Westerberg, H., 1992. The distribution of the scleractinian coral Lophelia pertusa around the Faroe Islands and relation to tidal mixing. Sarsia, 77:157-171.

Freiwald, A., Fossa, J.H., Grehan, A., Koslow, T., and Roberts, J.M., 2004. Cold-water coral reefs: out of sight-no longer out of mind. UNEP/WCMC Rep., Biodiversity Ser., 22.

Freiwald, A., Henrich, R., and Pätzold, J., 1997. Anatomy of a deep-water coral reef mound from Stjernsund, WestFinnmark, Northern Norway. Spec. Publ.-SEPM (Soc. Sediment. Geol.), 56:141-162.

Games, K.P., 2001. Evidence of shallow gas above the Connemara oil accumulation, Block 26/28, Porcupine Basin. In Shannon, P.M., Haughton, P., and Corcoran, D. (Eds.), Petroleum Exploration of Ireland's Offshore Basins. Geol. Soc. Spec. Publ., 188:361-373.
Haug, G.H., and Tiedemann, R., 1998. Effect of the formation of the Isthmus of Panama on Atlantic Ocean thermohaline circulation. Nature (London, U. K.), 393:673676. doi:10.1038/31447

Henriet, J.-P., De Mol, B., Pillen, S., Vanneste, M., Van Rooij, D., Versteeg, W., Croker, P.F., Shannon, P., Unnithan, V., Bouriak, S., Chachkine, P., and the Porcupine-Belgica 97 Shipboard Party, 1998. Gas hydrate crystals may help build reefs. Nature (London, U. K.), 391:648-649. doi:10.1038/35530

Henriet, J.-P., De Mol, B., Vanneste, M., Huvenne, V., Van Rooij, D., and the Porcupine-Belgica 97, 98, and 99 Shipboard Parties, 2001. Carbonate mounds and slope failures in the Porcupine Basin: a development model involving fluid venting. In Shannon, P.M., Haughton, P., and Corcoran, D. (Eds.), Petroleum Exploration of Ireland's Offshore Basins. Geol. Soc. Spec. Publ., 188:375383.

Henriet, J.-P., Guidard, S., and the ODP Proposal 573 Team, 2002. Carbonate mounds as a possible example for microbial activity in geological processes. In Wefer, G., Billet, D., Hebbeln, D., Joergensen, B., and van Weering, Tj. (Eds.), Ocean Margin Systems: Heidelberg (SpringerVerlag), 439-455.

Hovland, M., Croker, P.F., and Martin, M., 1994. Fault-associated seabed mounds (carbonate knolls?) off western Ireland and north-west Australia. Mar. Pet. Geol., 11:232-246. doi:10.1016/0264-8172(94)90099-X

Hovland, M., Mortensen, P.B., Brattegard, T., Strass, P., and Rokengen, K., 1998. Ahermatypic coral banks off midNorway: evidence for a link with seepage of light hydrocarbons. Palaios, 13:189-200.

Huvenne, V., De Mol, B., and Henriet, J.-P., 2003. A 3D seismic study of the morphology and spatial distribution of buried mounds in the Porcupine Seabight. Mar. Geol., 198:5-25. doi:10.1016/S0025-3227(03)00092-6

Huvenne, V.A.I., Beyer, A., de Haas, H., Dekindt, K., Henriet, J.-P., Kozachenko, M., Olu-Le Roy, K., Wheeler, A.J., and TOBI/Pelagia 197 and CARACOLE participants, 2005. The seabed appearance of different coral bank provinces in the Porcupine Seabight, NE Atlantic: results from sidescan sonar and ROV seabed mapping. In Freiwald, A., and Roberts, J.M. (Eds.), Cold-Water Corals and Ecosystems: Heidelberg (Springer-Verlag), 535569.

James, N.P., Feary, D.A., Surlyk, F., Simo, J.A., Betzler, C., Holbourn, A.E., Li, Q., Matsuda, H., Machiyama, H., Brooks, G.R., Andres, M.S., Hine, A.C., Malone, M.J., and the ODP Leg 182 Science Party, 2000. Quaternary bryozoan reef mounds in cool-water, upper slope environments: Great Australian Bight. Geology, 28:647-650. doi:10.1130/0091-7613(2000)028<0647:QBR$\mathrm{MIC}>2.3 . \mathrm{CO} ; 2$

Jansen, E., Raymo, M.E., Blum, P., et al., 1996. Proc. ODP, Init. Repts., 162: College Station, TX (Ocean Drilling Program).

Johnston, S., Doré, A.G., and Spencer, A.M., 2001. The Mesozoic evolution of the southern North Atlantic region and its relationship to basin development in the south Porcupine Basin, offshore Ireland. In Shannon, 
P.M., Haughton, P., and Corcoran, D. (Eds.), Petroleum Exploration of Ireland's Offshore Basins. Geol. Soc. Spec. Publ., 188:237-263.

Kaufmann, B., 1997. Diagenesis of middle Devonian carbonate mounds of the Mader Basin (eastern Anti-Atlas, Morocco). J. Sediment. Res., A67:945-956.

Kenyon, N.H., Belderson, R.H., and Stride, A.H., 1978. Channels, canyons and slump folds between southwest Ireland and Spain. Oceanol. Acta, 1(3):369-380.

Kenyon, N.H., Akhmetzhanov, A.M., Wheeler, A.J., van Weering, T.C.E., de Haas, H., and Ivanov, M.K., 2003. Giant carbonate mud mounds in the southern Rockall Trough. Mar. Geol., 195:5-30. doi:10.1016/S00253227(02)00680-1

Lees, A., 1988. Waulsortian reefs: the history of a concept. Mem. Inst. Geol. Univ. Louvain, 34:43-55.

Maldonado, A., and Nelson, C.H., 1999. Interaction of tectonic and depositional processes that control the evolution of the Iberian Gulf of Cadiz margin. Mar. Geol., 155:217-242. doi:10.1016/S0025-3227(98)00148-0

McDonnell, A., and Shannon, P.M., 2001. Comparative Tertiary stratigraphic evolution of the Porcupine and Rockall Basins. In Shannon, P.M., Haughton, P., and Corcoran, D. (Eds.), Petroleum Exploration of Ireland's Offshore Basins. Geol. Soc. Spec. Publ., 188:323-344.

Moore, J.G., and Shannon, P.M., 1991. Slump structures in the late Tertiary of the Porcupine Basin, offshore Ireland. Mar. Pet. Geol., 8:184-197. doi:10.1016/02648172(91)90006-M

Moore, J.G., and Shannon, P.M., 1995. The Cretaceous succession in the Porcupine Basin, offshore Ireland: facies distribution and hydrocarbon potential. In Croker, P.F., and Shannon, P.M. (Eds.), The Petroleum Geology of Ireland's Offshore Basins. Geol. Soc. Spec. Publ., 93:345370.

Naeth, J., di Primio, R., Horsfield, B., Schaefer, R.G., Shannon, P.M., Bailey, W.R., and Henriet, J.-P., 2005. Hydrocarbon seepage and carbonate mound formation: a basin modelling study from the Porcupine basin (offshore Ireland). J. Petrol. Geol., 28:147-166.

Naylor, D., and Shannon, P.M., 1982. Geology of Offshore Ireland and West Britain: London (Graharn and Trotman).

Neumann, A.C., Kofoed, J.W., and Keller, G.H., 1977. Lithoherms in the Straits of Florida. Geology, 5:4-10. doi:10.1130/0091-7613(1977)5<4:LITSOF>2.0.CO;2

Pingree, R.D., and Le Cann, B., 1989. Celtic and Armorican slope and shelf residual currents. Prog. Oceanogr., 23:303-338.

Pingree, R.D., and Le Cann, B., 1990. Structure, strength and seasonality of the slope currents in the Bay of Biscay region. J. Mar. Biol. Assoc. U.K., 70:857-885.

Rice, A.L., Billet, D.S.M., Thurston, M.H., and Lampitt, R.S., 1991. The Institute of Oceanographic Sciences Biology programme in the Porcupine Seabight: back- ground and general introduction. J. Mar. Biol. Assoc. U. K., 71:281-310.

Riding, R., 1991. Calcified cyanobacteria. In Riding, R.

(Ed.), Calcareous Algae and Stromatolites: Berlin (Springer-Verlag), 55-87.

Rogers, A.D., 1999. The biology of Lophelia pertusa (Linnaeus, 1758) and other deep-water reef-forming corals and impacts from human activities. Intern. Rev. Hydrobiol., 84:315-06.

Rüggeberg, A., Dorschel, B., Dullo, W.-C., and Hebbeln, D., 2005. Sedimentary patterns in the vicinity of a carbonate mound in the Hovland mound province, northern Porcupine Seabight. In Freiwold, A., and Roberts, M. (Eds.), Cold-Water Corals and Ecosystems: Heidelberg (Springer-Verlag), 87-112.

Shannon, P.M., 1991. The development of Irish offshore sedimentary basins. J. Geol. Soc. (U. K.), 148:181-189.

Somerville, I.D., 2003. Review of Irish lower carboniferous (Mississippian) mud-mounds: depositional setting, biota, facies and evolution. In Ahr, W.M., Harris, P.M., Morgan, W.A., and Somerville, I.D. (Eds), Permo-Carboniferous Carbonate Platforms and Reefs. Spec. Publ.-SEPM (Soc. Sediment. Geol.), 78:239-252.

Teichert, C., 1958. Cold- and deep-water coral banks. Bull. Am. Assoc. Pet. Geol., 42:1064-1082.

Tudhope, A.W., and Scoffin, T.P., 1995. Processes of sedimentation in Gollum Channel, Porcupine Seabight: submersible observations and sediment analyses. Trans. R. Soc. Edinburgh: Earth Sci., 86:49-55.

Van Rooij, D., 2004. An integrated study of Quaternary sedimentary processes on the eastern slope of the Porcupine Seabight, SW of Ireland [Ph.D. dissert.]. Ghent Univ., Belgium.

Van Rooij, D., De Mol, B., Huvenne, V., Ivanov, M., and Henriet, J.-P., 2003. Seismic evidence of current-controlled sedimentation in the Belgica mound province, upper Porcupine slope, SW of Ireland. Mar. Geol., 195(14):31-53. doi:10.1016/S0025-3227(02)00681-3

Wheeler, A.J., Kozachenko, M., Beyer, A., Foubert, A., Huvenne, V.A.I., Klages, M., Masson, D.G., Olu-Le Roy, K., and Thiede, J., 2005. Sedimentary processes and carbonate mound morphology in the Belgica mound province, Porcupine Seabight, NE Atlantic. In Freiwald, A., and Roberts, M. (Eds.), Cold-water Corals and Ecosystems: Heidelberg (Springer-Verlag), 517-603.

White, M., 2001. Hydrography and physical dynamics at the NE Atlantic margin that influence the deep-water cold coral reef ecosystem-EU ACES-ECOMOUND Internal Report: Galway, Ireland (Dept. Oceanogr., NUI).

Ziegler, P.A., 1982. Geological Atlas of Western and Central Europe: Amsterdam (Elsevier).

Publication: 14 October 2006

MS 307-101 
Figure F1. Location of Porcupine Seabight; the Belgica, Hovland, and Magellan mound provinces; and Expedition 307 operations area.

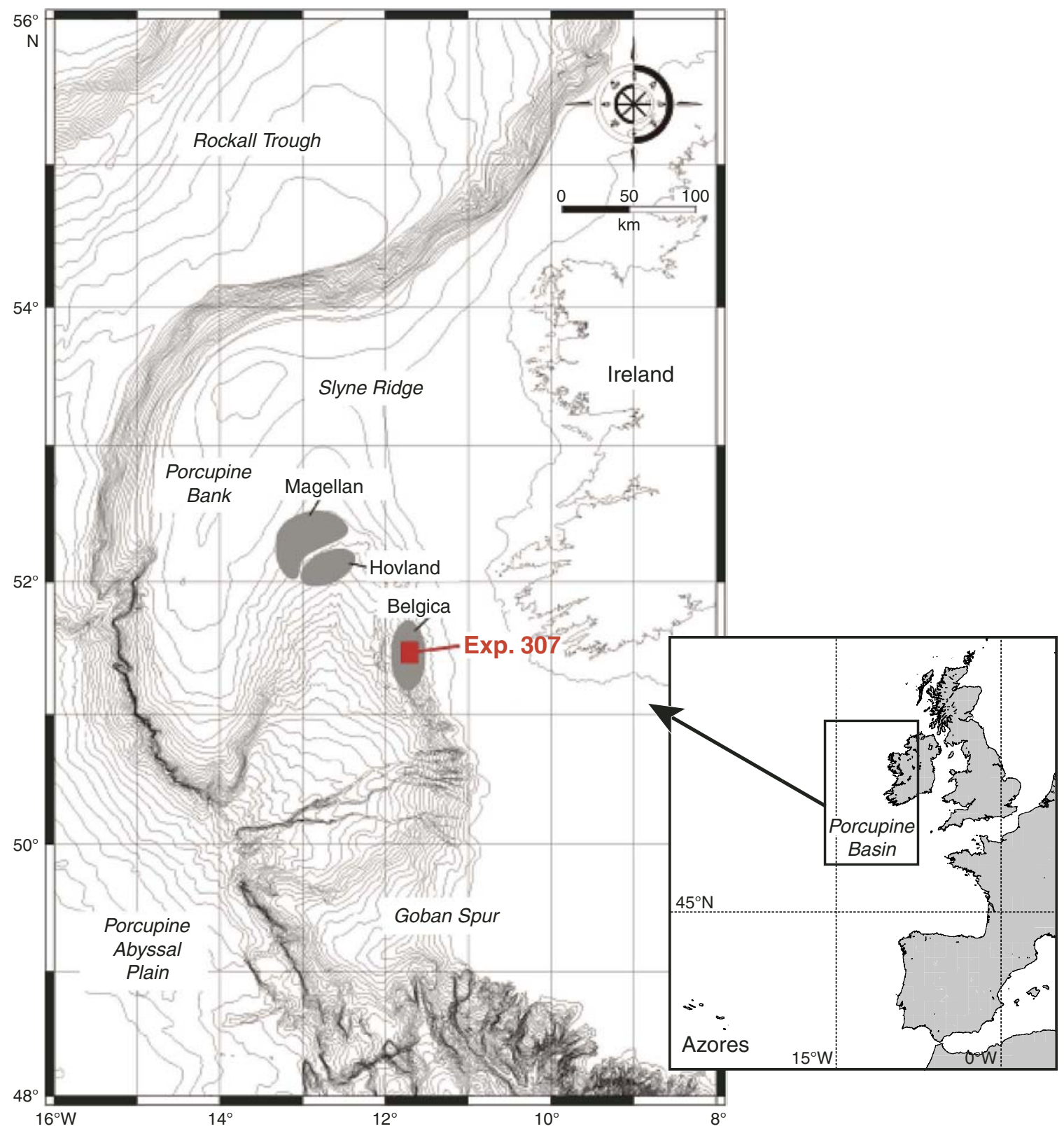


Figure F2. 3-D bathymetric view of outcropping Belgica mounds, Porcupine Seabight (based on AWI multibeam bathymetry [Beyer et al., 2003]).

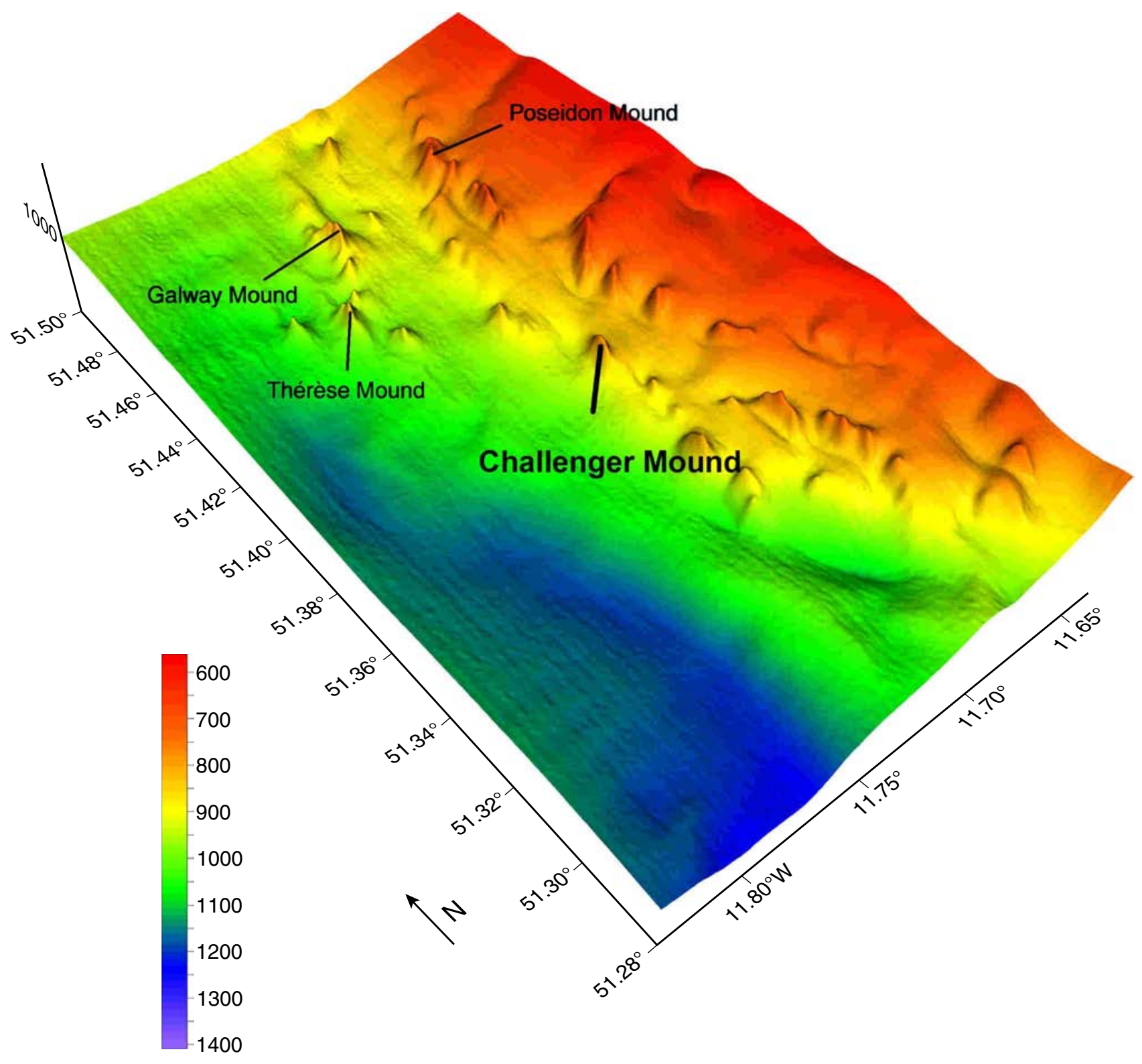


Figure F3. Interpretation of high-resolution seismic profile P980521 underlying Challenger Mound and slope (after De Mol et al., 2002).

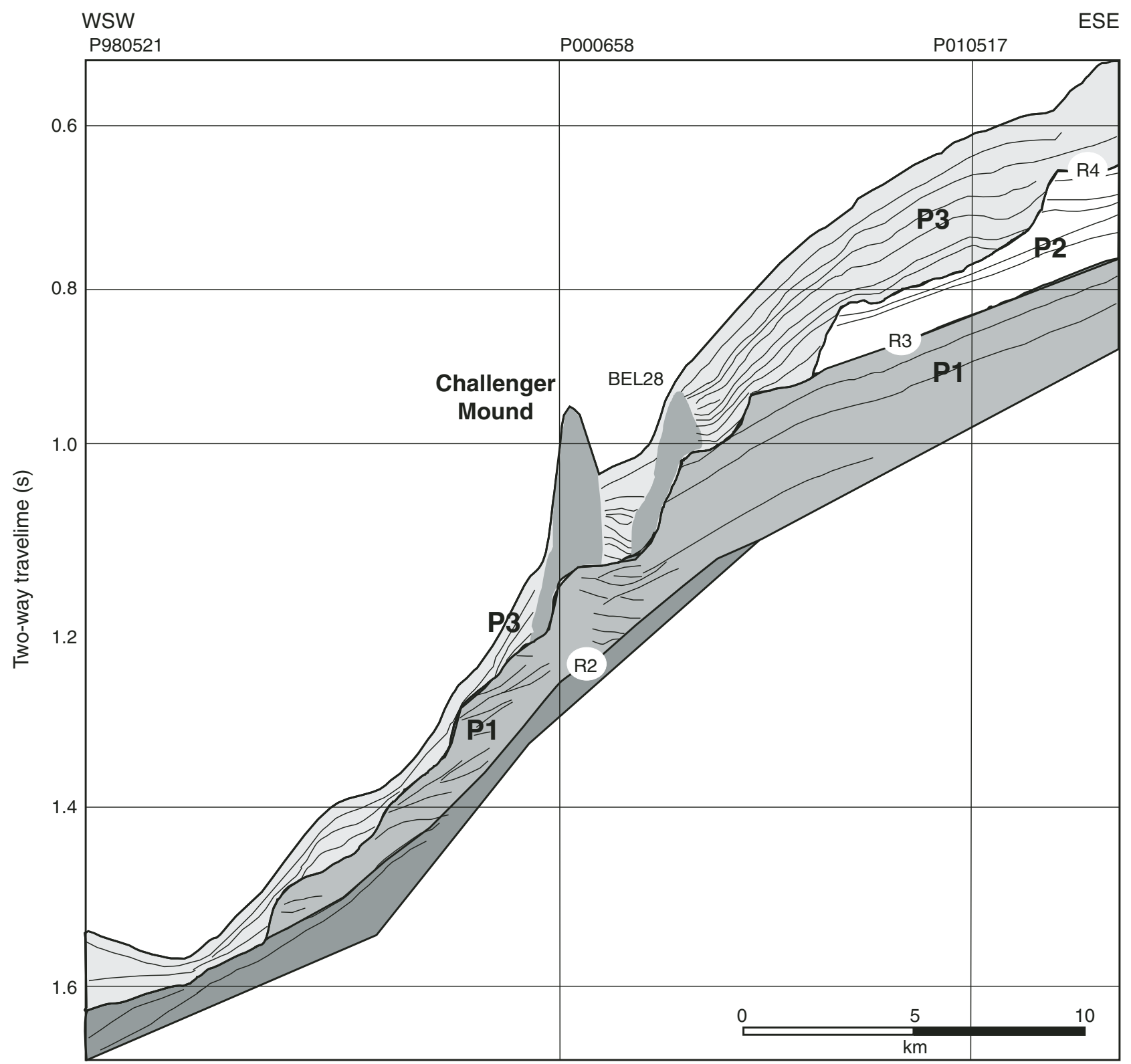


Figure F4. Geological interpretation of Porcupine Basin stratigraphy in the Belgica province (after Naeth et al., 2005). Arrows = modeled pathways of hydrocarbon-rich gases.

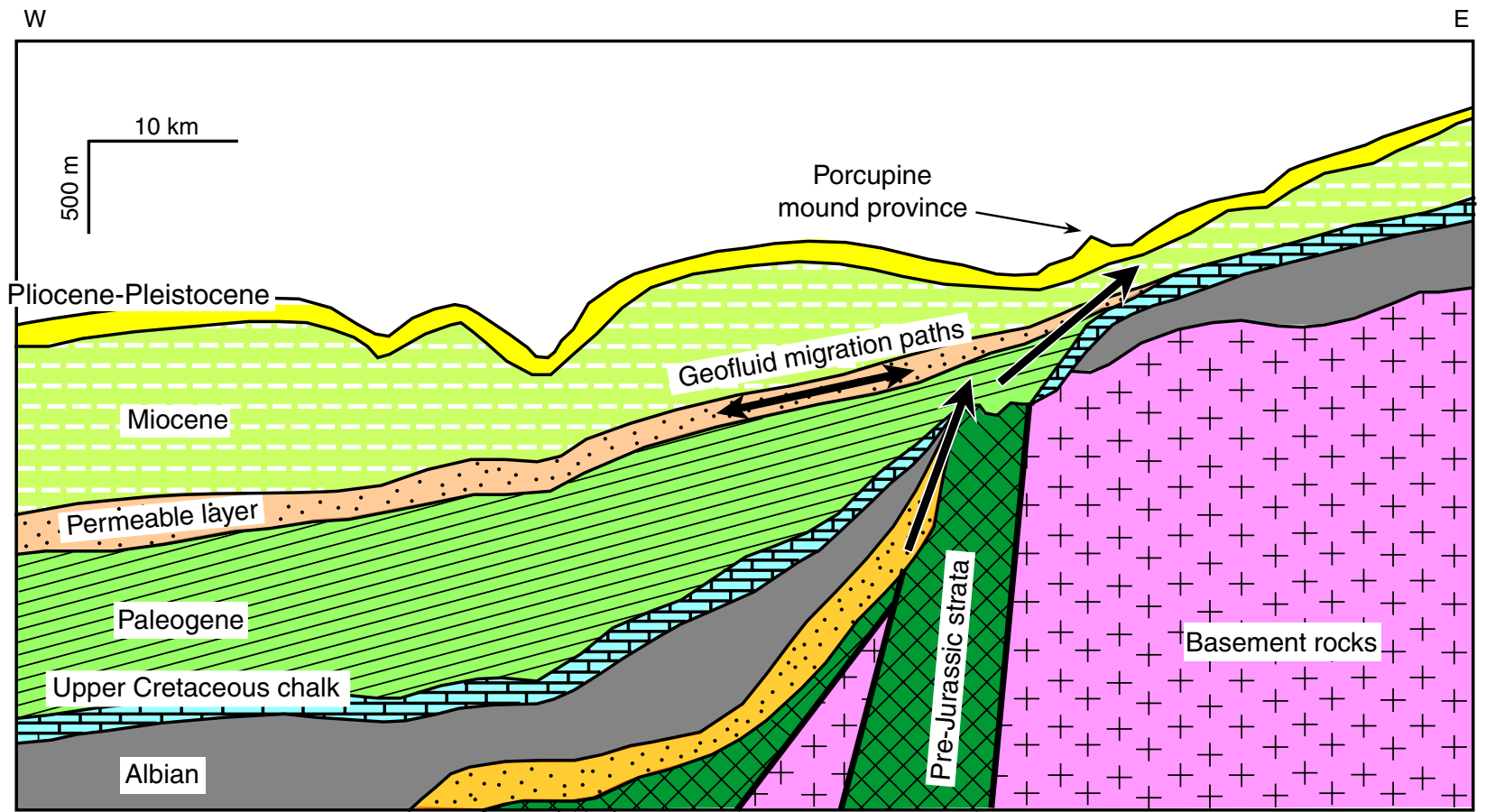


Figure F5. High-resolution seismic profile P000658 of Challenger Mound along a north-northwest to southsoutheast transect. Note the sigmoid shapes to both sides of the mound (Henriet et al., 2002).

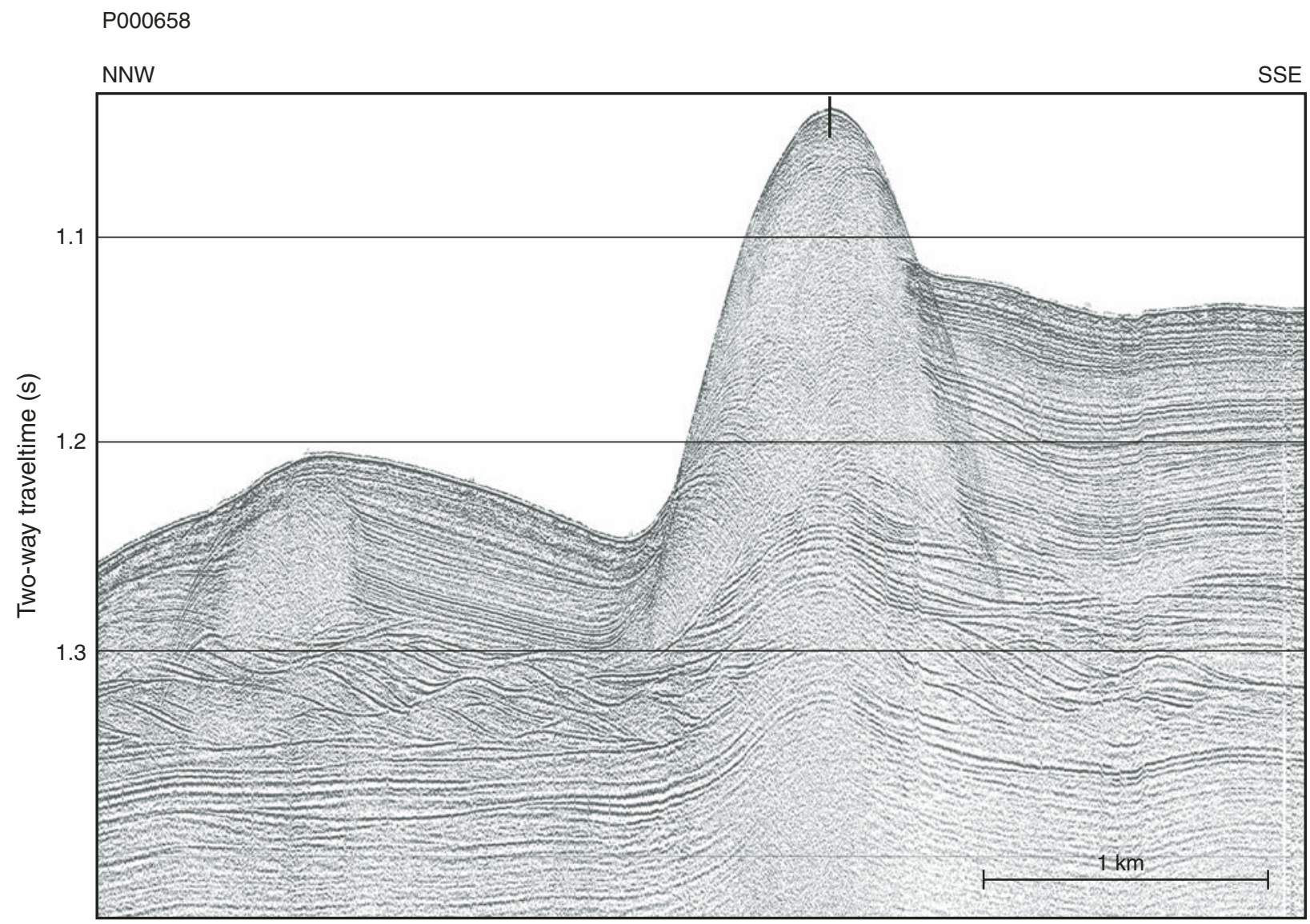


Figure F6. Location of Sites U1316, U1317, and U1318 in Porcupine Seabight.

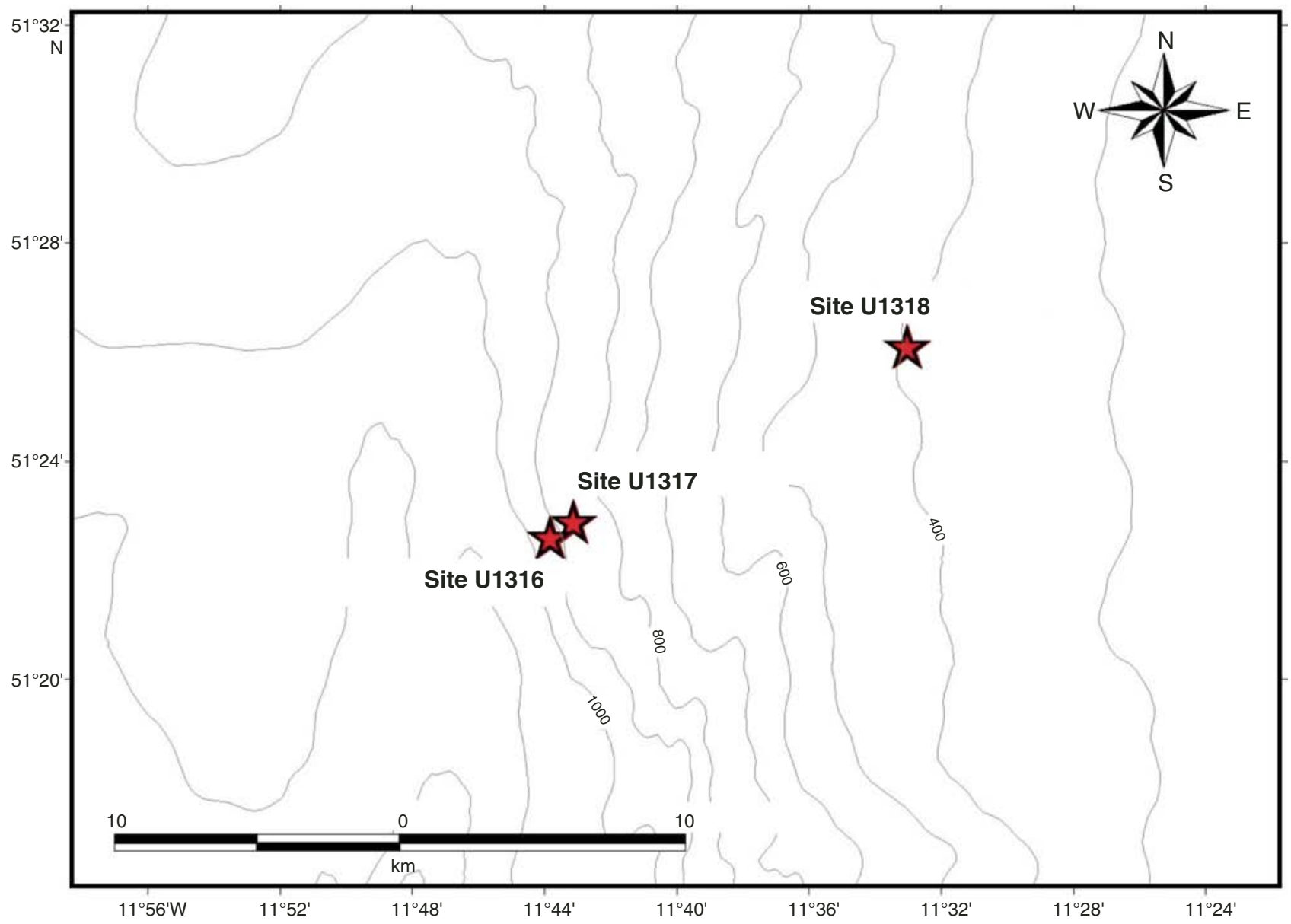


Figure F7. Location of Site U1317 Holes U1317A-U1317E and Site U1318 Holes U1318A-U1318C (multibeam bathymetry [Beyer et al., 2003]).

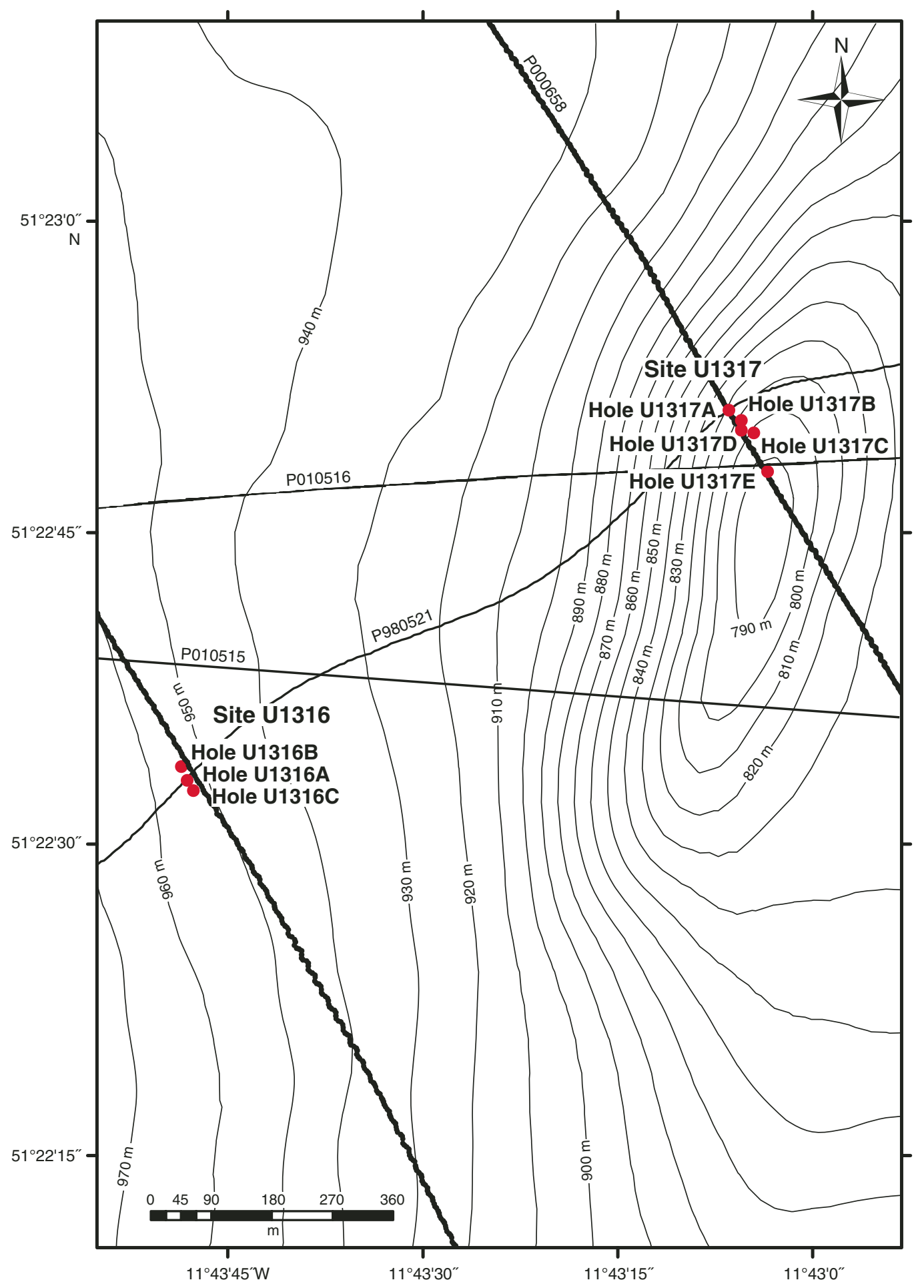


Figure F8. Lithostratigraphic correlation. Geologic ages were estimated from biostratigraphic data.

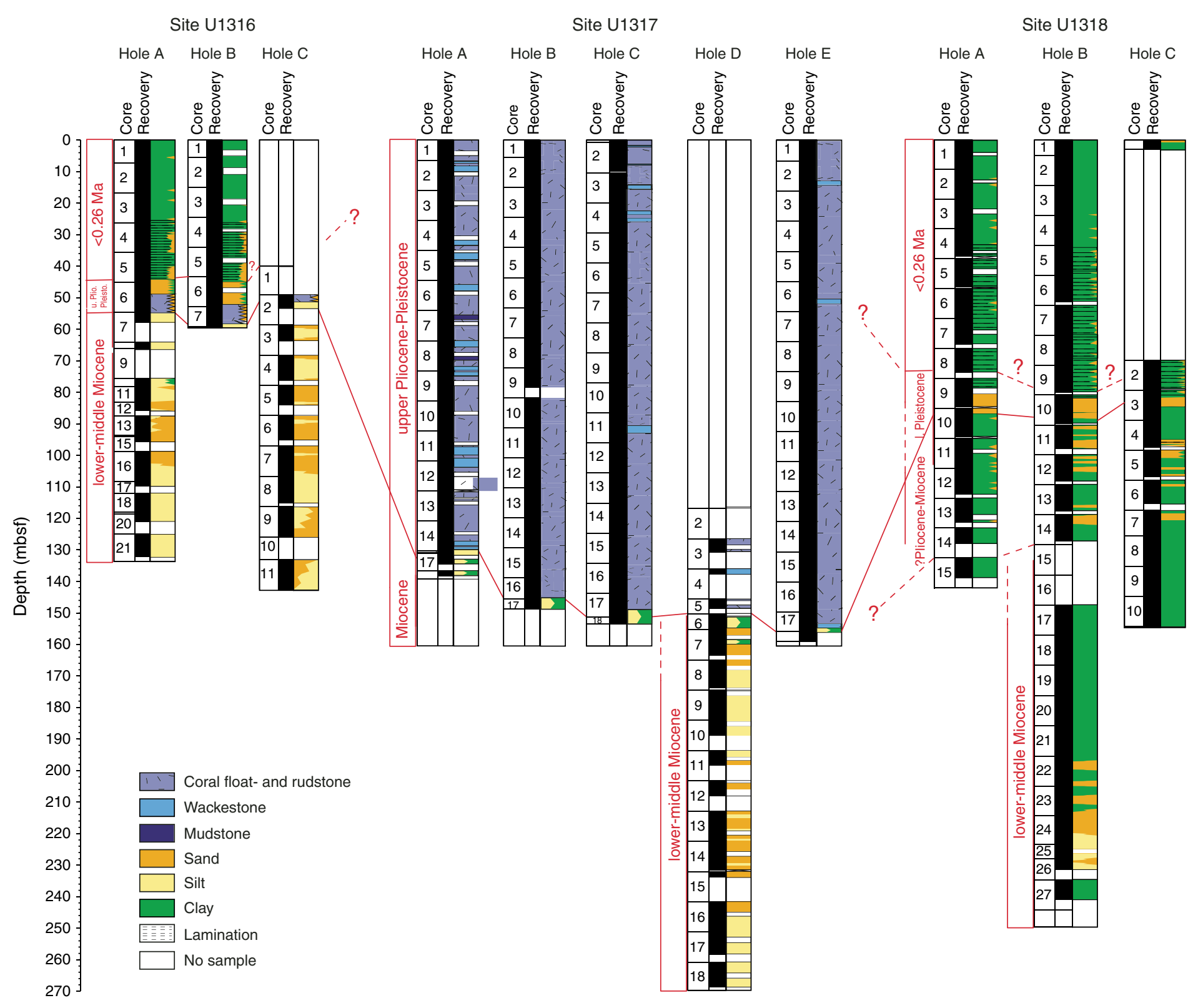


Figure F9. Lithostratigraphy of the three sites projected on the seismic profile of Challenger Mound along a north-northwest to south-southeast transect. P1-P3 refers to seismic units as defined by Van Rooij et al. (2003). Lithostratigraphic units are numbered next to the lithologic column. Based on the lithostratigraphic data, seismic Unit P3 is younger $(<0.26 \mathrm{Ma})$ than the upper mound succession.

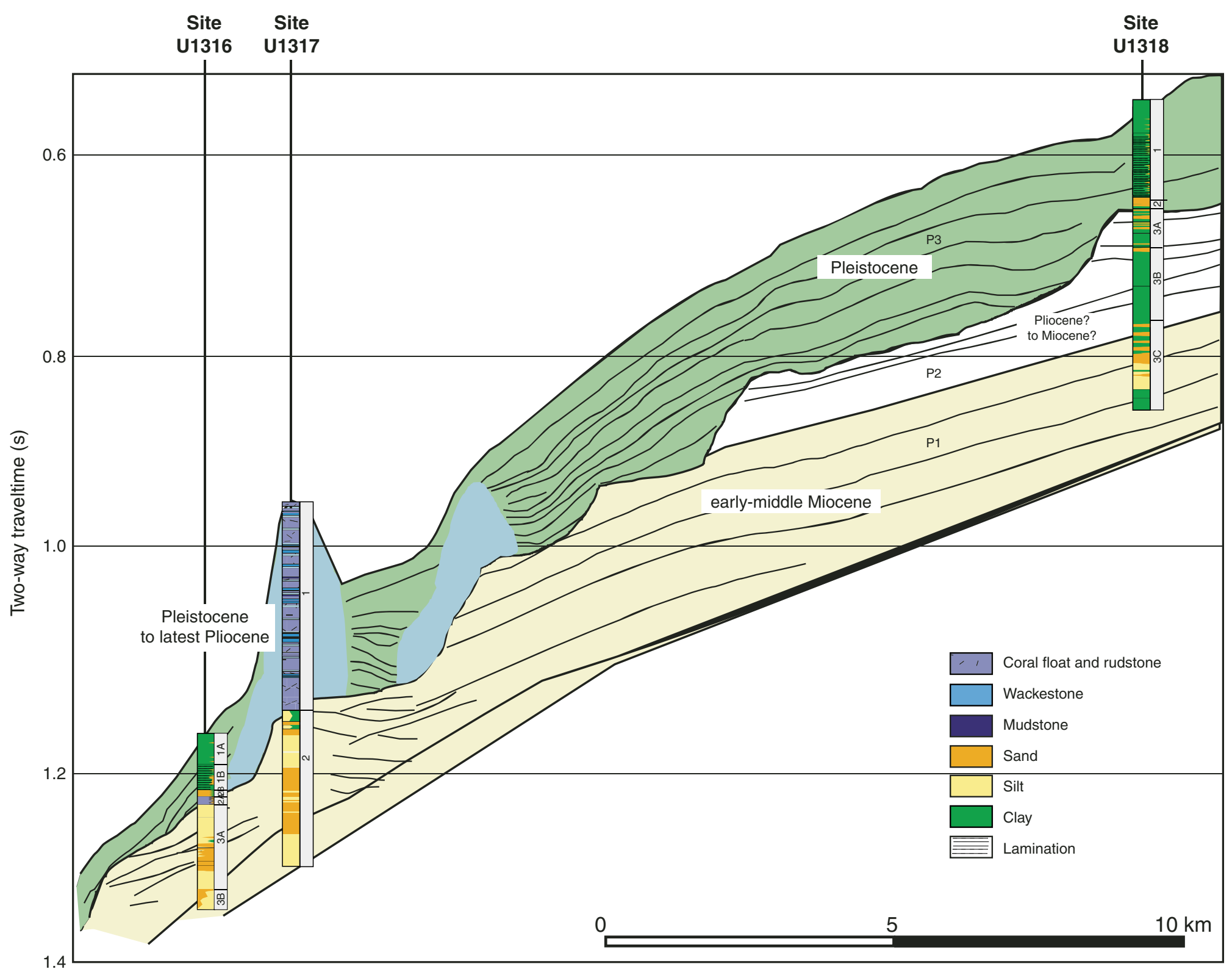


Figure F10. Correlation and interpretation of paleomagnetic inclination results.

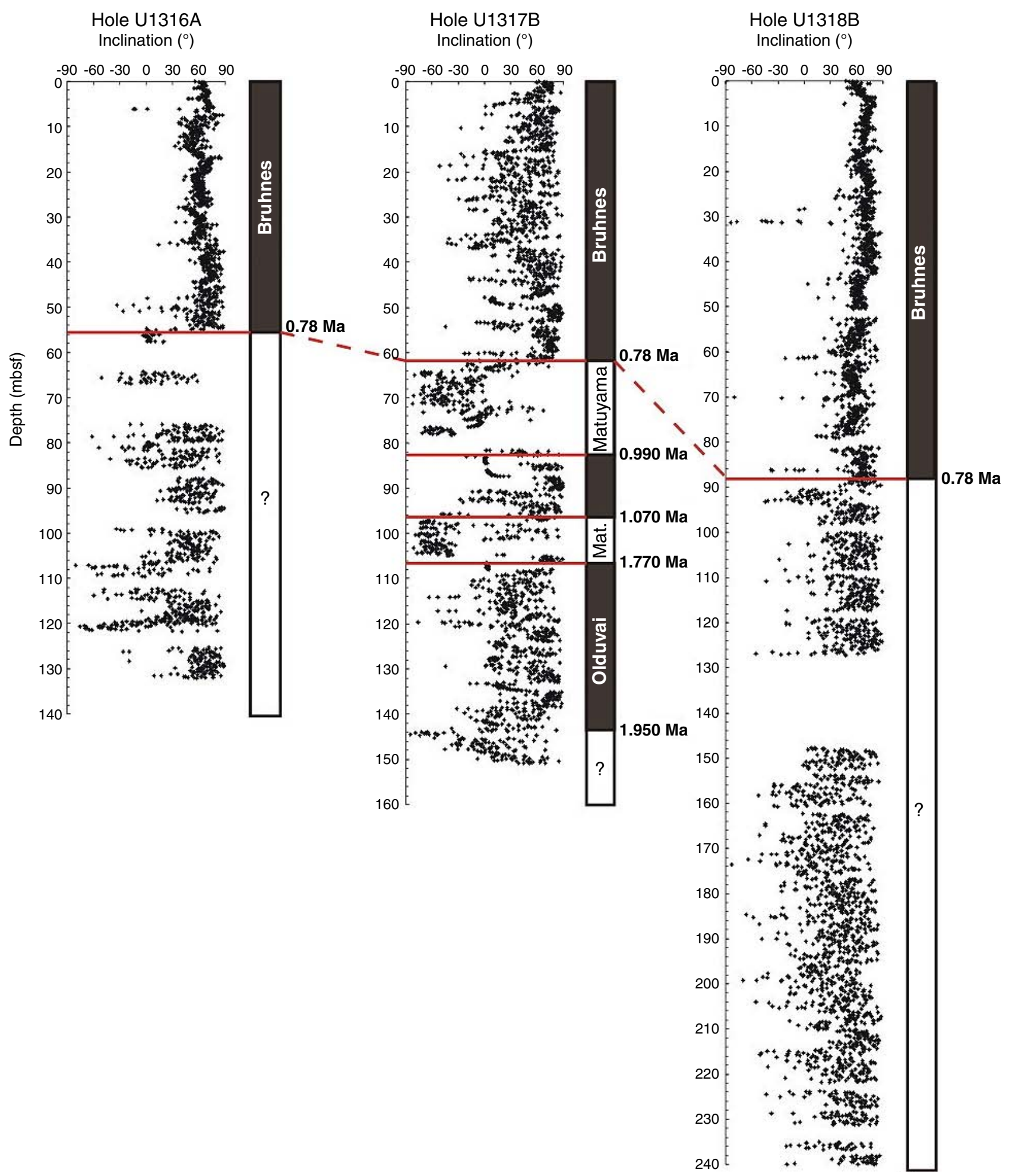


Figure F11. Depth profiles of prokaryote cell counts. Dotted line = global prokaryote profile (Parkes et al., 2000), dashed lines = upper and lower prediction limits for this profile. $\mathrm{MB}=$ mound base.

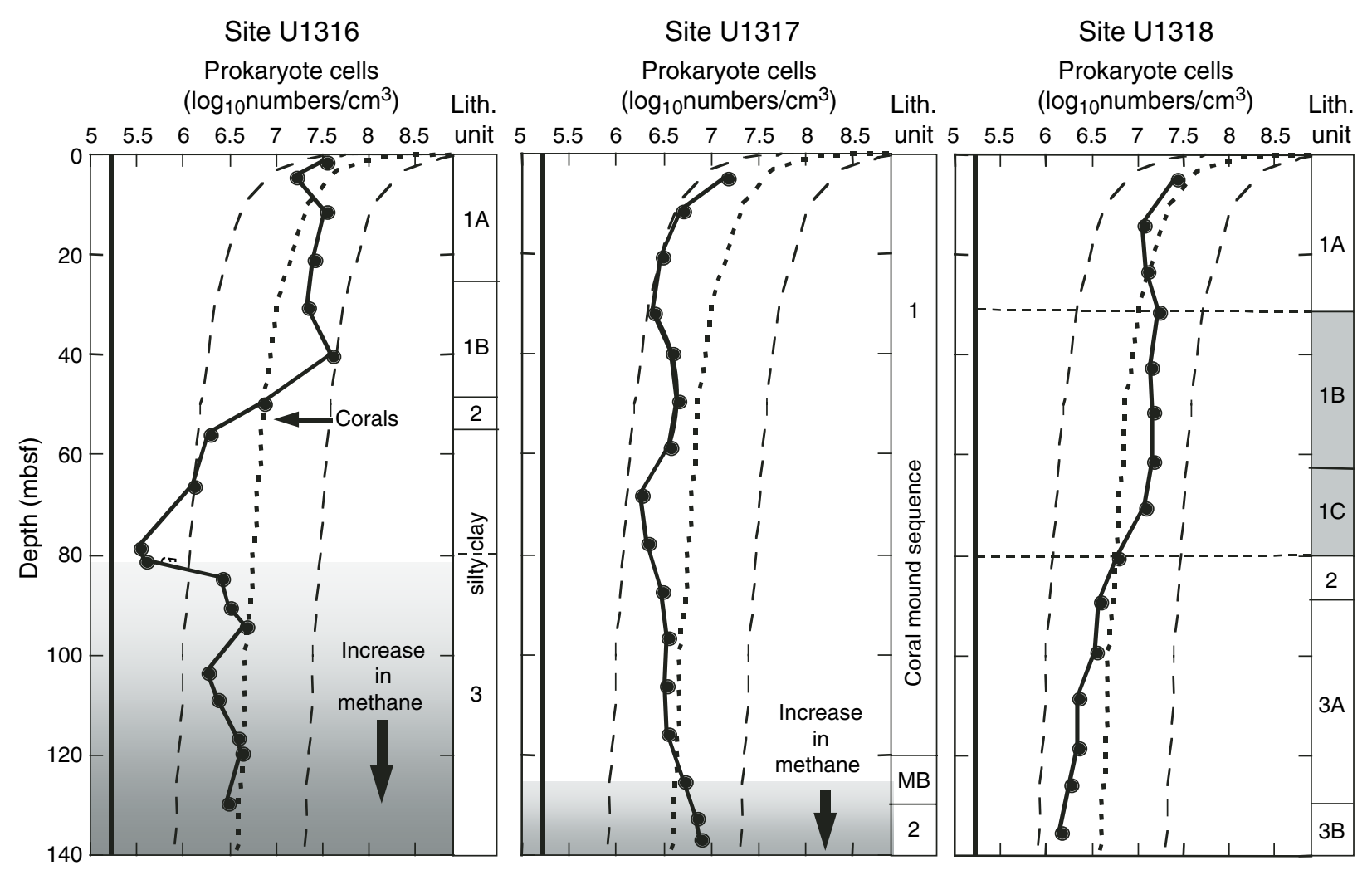


Figure F12. Spatial correlation of natural gamma radiation (NGR) data of lithostratigraphic Unit 1 from Site U1317.

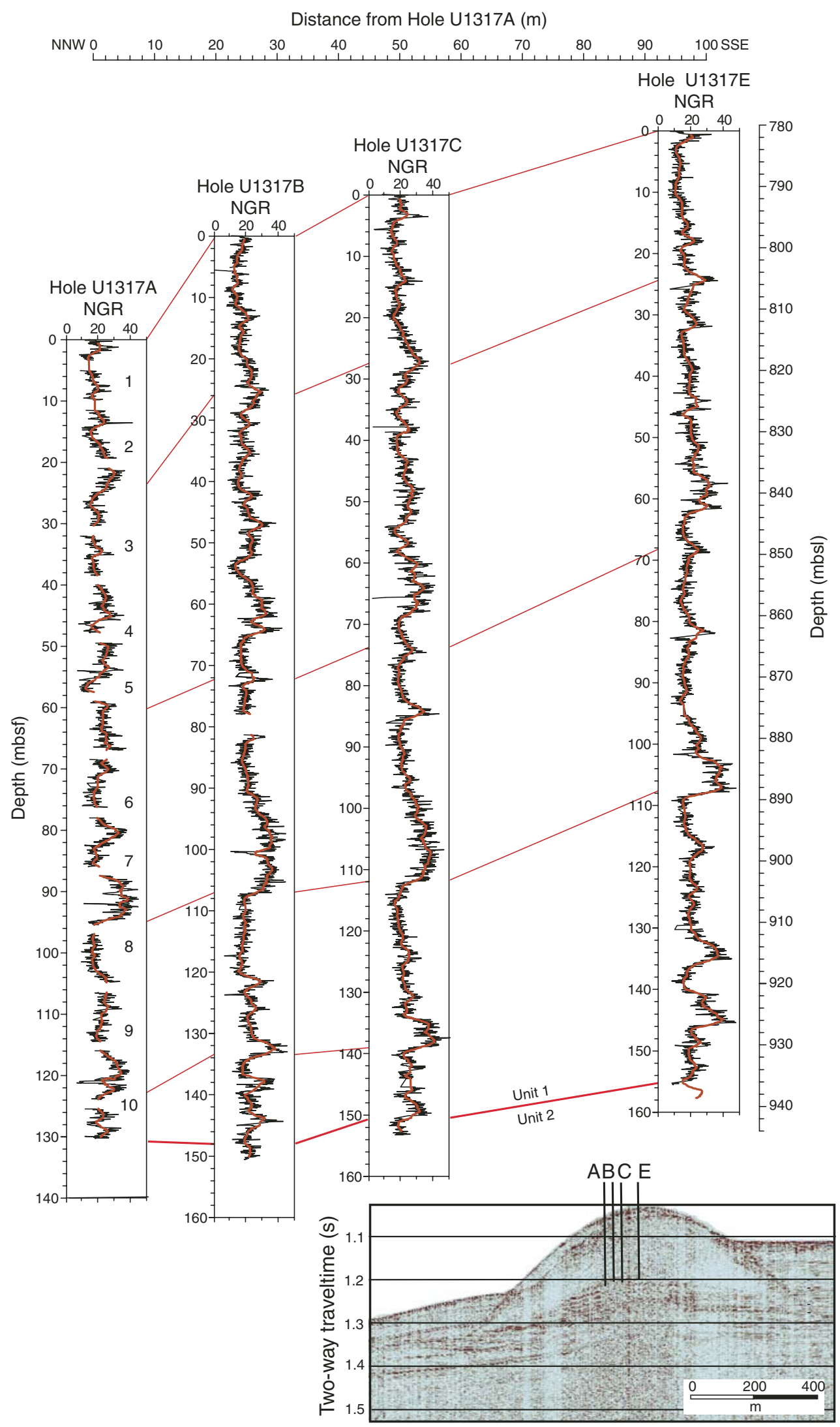


Figure F13. Comparison of mound base close-up photographs from Sites U1316 and U1317.

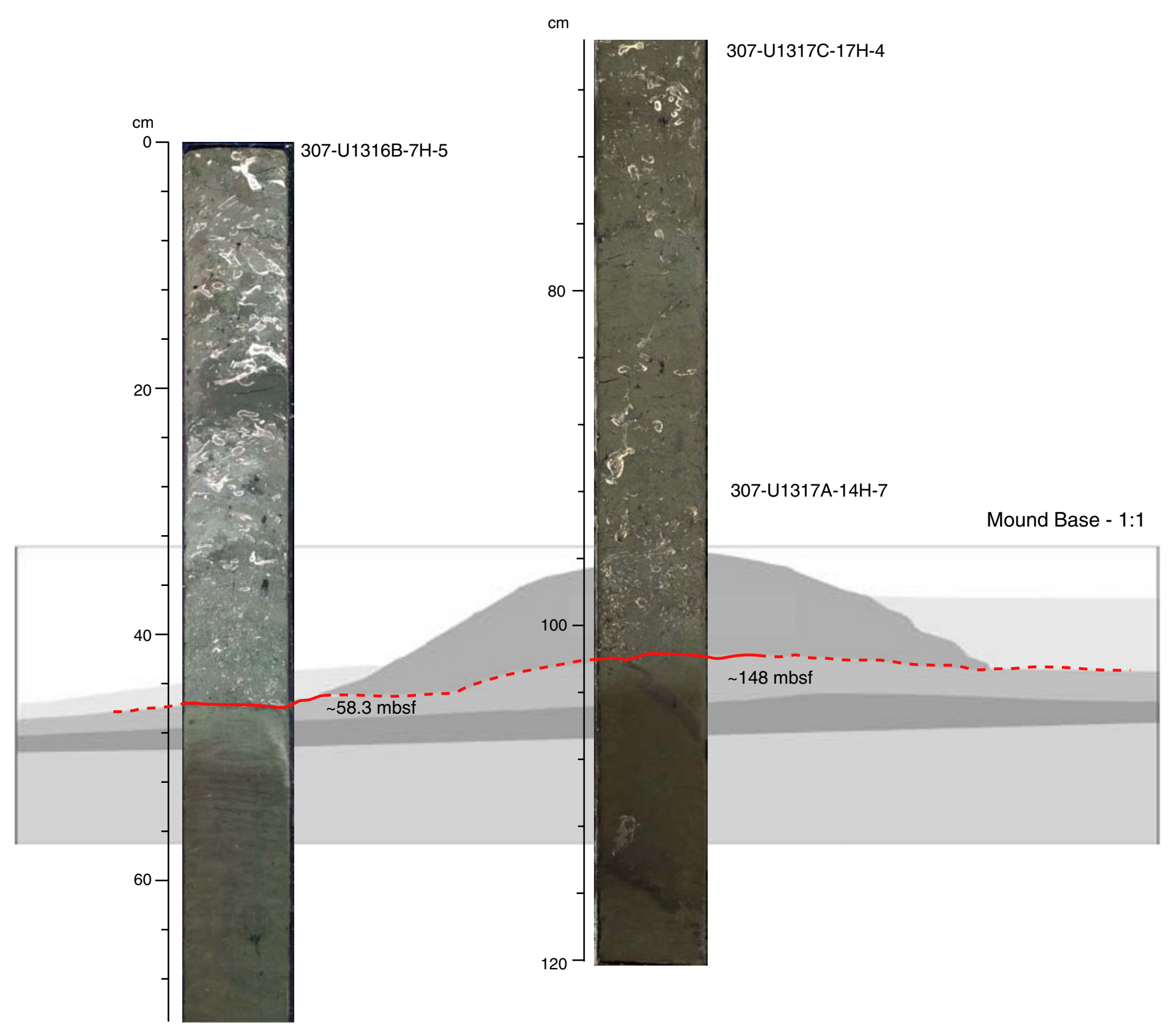


Figure F14. Acoustic velocity profiles at Site U1317 measured by three different methods. Solid circles and squares $=$ core measurements, black line $=$ check shot interval velocities. $\mathrm{PWS}=P$-wave sensor, $\mathrm{PWL}=P$-wave logger.

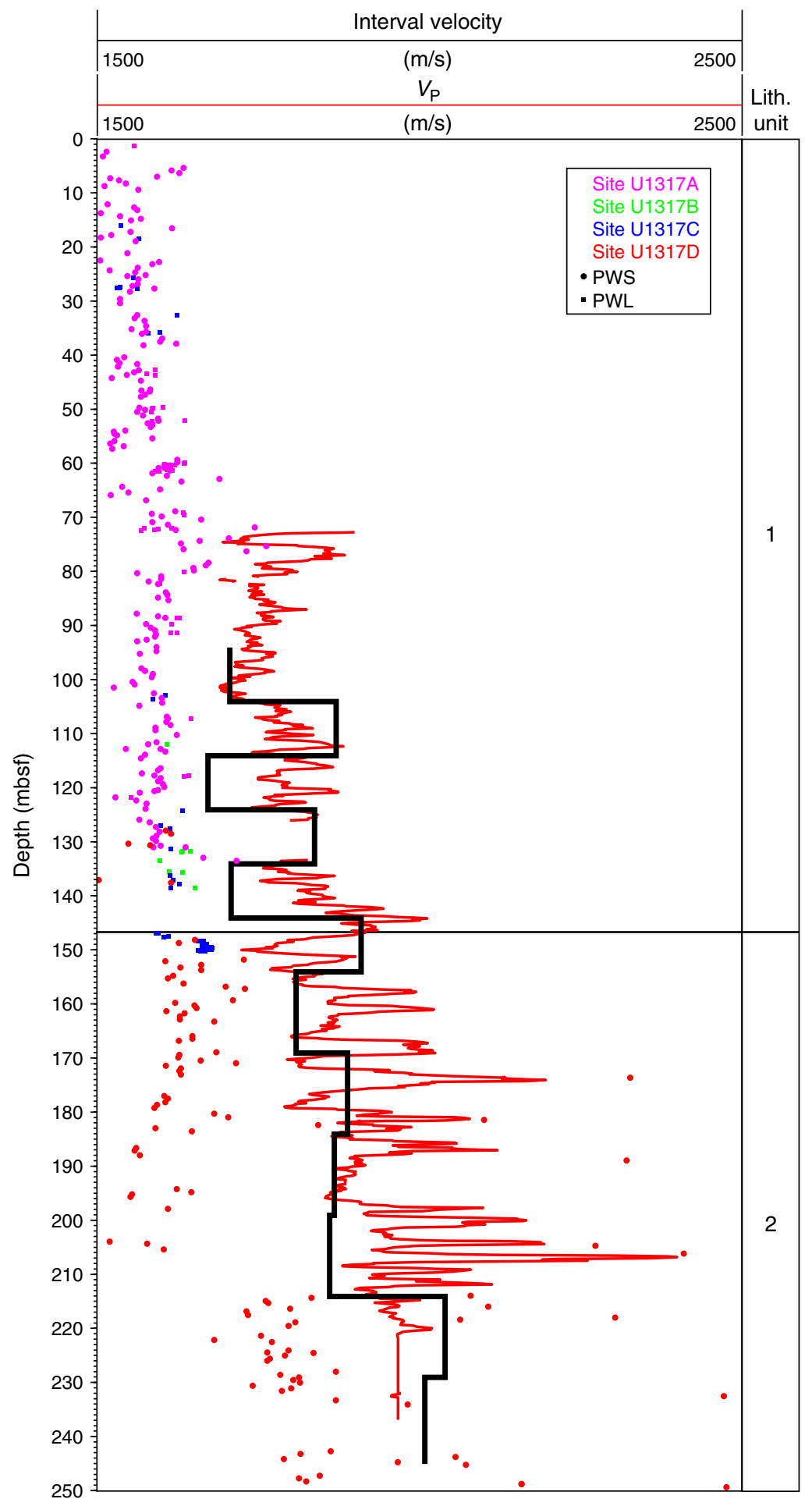


Figure F15. Geochemical profiles of interstitial water and gas collected in Holes U1317A, U1317D, and U1317E. Solid circles = Hole U1317A, open diamonds $=$ Hole U1317D, open squares = Hole U1317E. Yellow bar delineates zone of organoclastic sulfate reduction and carbonate diagenesis in the upper part of the mound. Orange bar delineates zone of sulfate reduction associated with the anaerobic oxidation of methane.

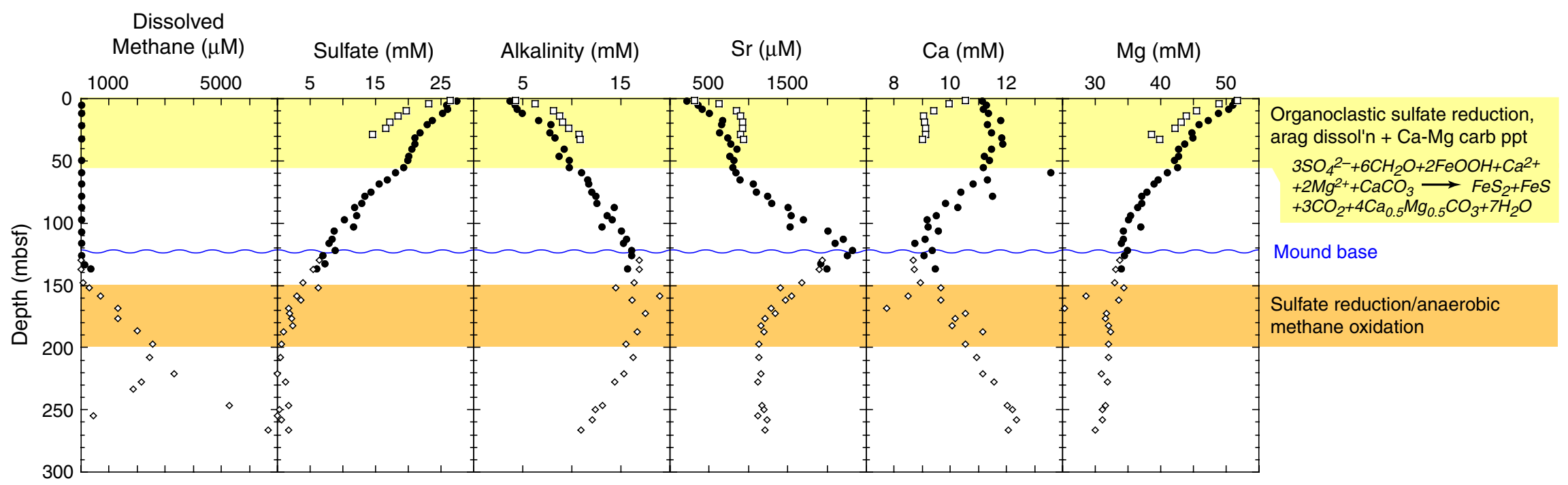


Figure F16. Example of a CT scan from Hole U1317E (Siemens Somatom Sensation 64).

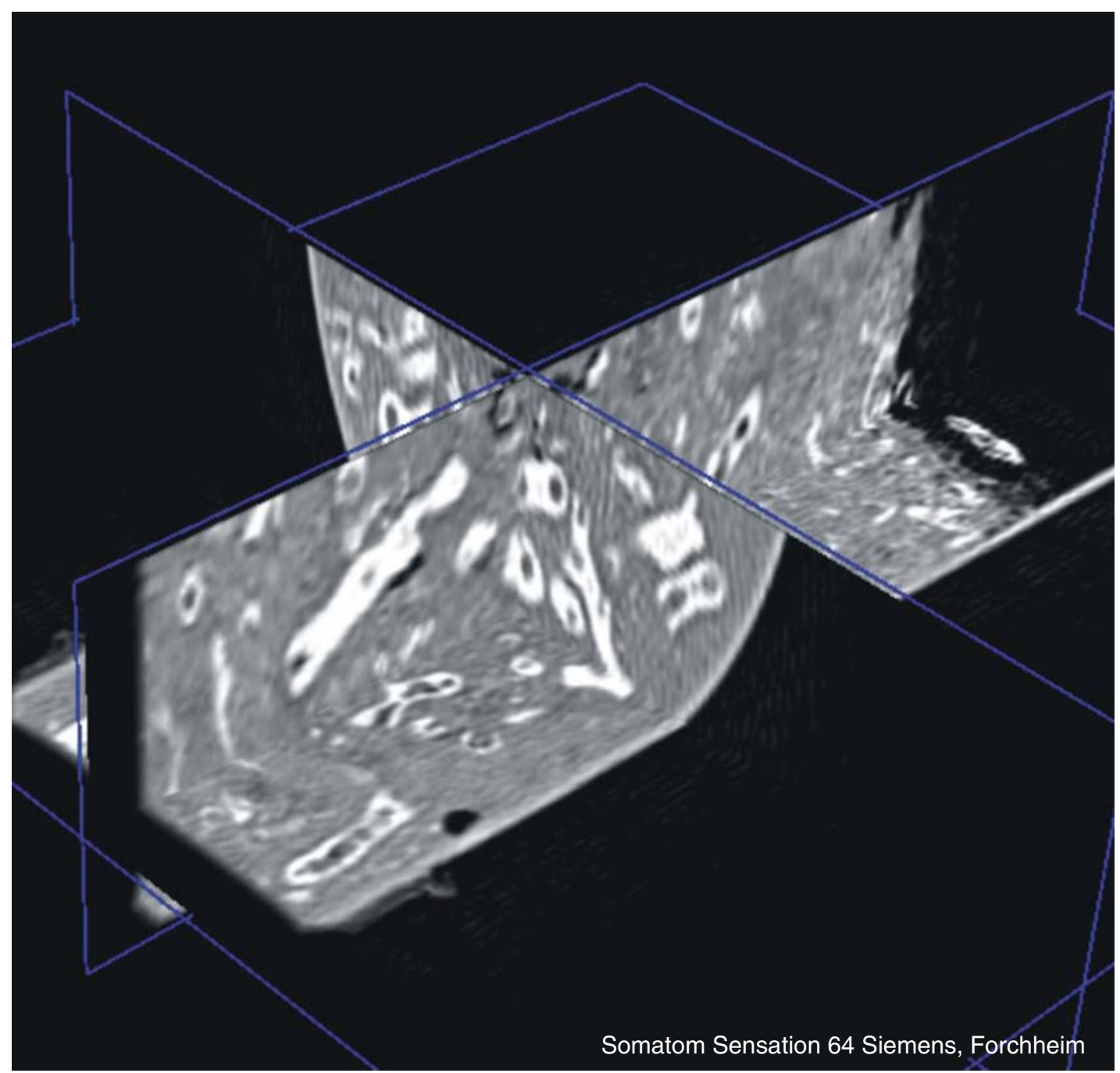


Figure F17. Comparison of core split (A) conventionally (interval 307-U1317A-14H-2, 16-28 cm) and (B) while frozen (interval 307-U1317C-13H-5, 90-103 cm).
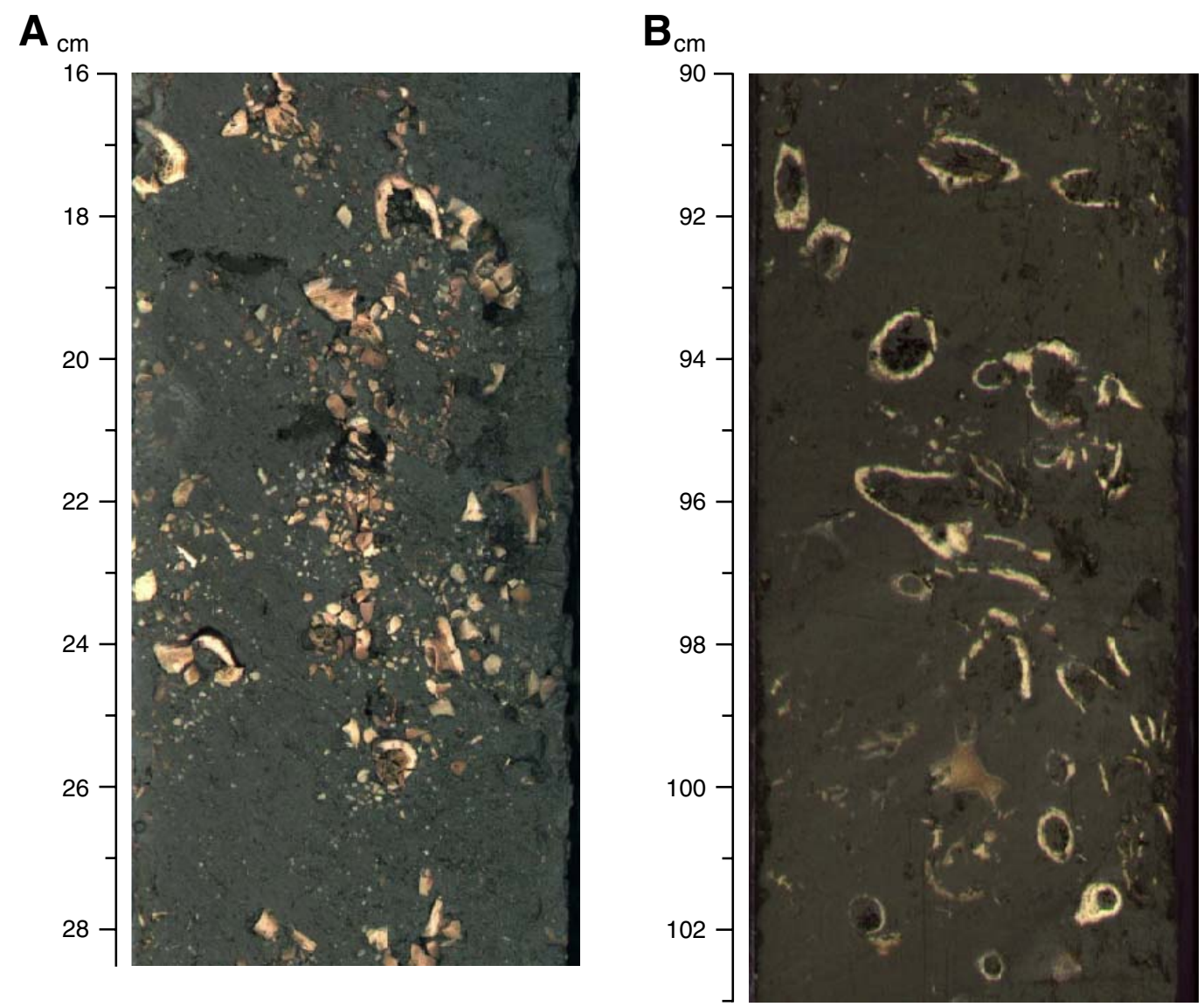
Table T1. Expedition 307 coring summary.

\begin{tabular}{|c|c|c|c|c|c|c|c|c|c|c|c|c|c|c|c|c|c|}
\hline \multirow[b]{2}{*}{$\begin{array}{l}\text { Proposed } \\
\text { site }\end{array}$} & \multirow[b]{2}{*}{ Hole } & \multicolumn{4}{|c|}{ Advanced piston corer } & \multicolumn{4}{|c|}{ Extended core barrel } & \multicolumn{4}{|c|}{ Rotary core barrel } & \multicolumn{4}{|c|}{ Total coring statistics } \\
\hline & & N & $\begin{array}{c}\text { Interval } \\
(\mathrm{m})\end{array}$ & $\begin{array}{l}\text { Recovered } \\
\text { (m) }\end{array}$ & Recovery (\%) & $N$ & $\begin{array}{c}\text { Interval } \\
(\mathrm{m})\end{array}$ & $\begin{array}{l}\text { Recovered } \\
\text { (m) }\end{array}$ & $\begin{array}{c}\text { Recovery } \\
\text { (\%) }\end{array}$ & $N$ & $\begin{array}{c}\text { Interval } \\
(\mathrm{m})\end{array}$ & $\begin{array}{l}\text { Recovered } \\
\text { (m) }\end{array}$ & $\begin{array}{l}\text { Recovery } \\
(\%)\end{array}$ & N & $\begin{array}{l}\text { Interval } \\
(\mathrm{m})\end{array}$ & $\begin{array}{l}\text { Recovered } \\
\text { (m) }\end{array}$ & $\begin{array}{c}\text { Recovery } \\
\text { (\%) }\end{array}$ \\
\hline \multirow[t]{3}{*}{ PORC-04A } & U1316A & 8 & 66.3 & 63.02 & 95.1 & 13 & 67.7 & 54.25 & 80.1 & 0 & 0.0 & 0.00 & NA & 21 & 134.0 & 117.27 & 87.5 \\
\hline & U1316B & 8 & 59.5 & 61.53 & 103.4 & 0 & 0.0 & 0.00 & 0.0 & 0 & 0.0 & 0.00 & NA & 8 & 59.5 & 61.53 & 104.5 \\
\hline & U1316C & 0 & 0.0 & 0.00 & NA & 0 & 0.0 & 0.00 & 0.0 & 11 & 103.1 & 70.15 & 68.0 & 11 & 103.1 & 70.15 & 68.0 \\
\hline \multicolumn{2}{|c|}{ Site U1316 totals: } & 16 & 125.8 & 124.55 & 99.0 & 13 & 67.7 & 54.25 & 63.0 & 11 & 103.1 & 70.15 & NA & 40 & 296.6 & 248.95 & 83.9 \\
\hline \multirow{5}{*}{ PORC-03A } & U1317A & 16 & 130.8 & 127.08 & 97.2 & 2 & 8.0 & 5.04 & 63.0 & 0 & 0.0 & 0.00 & NA & 18 & 138.8 & 132.12 & 95.2 \\
\hline & U1317B & 16 & 145.2 & 147.31 & 101.5 & 1 & 3.0 & 6.24 & 208.0 & 0 & 0.0 & 0.00 & NA & 17 & 148.2 & 153.55 & 103.6 \\
\hline & U1317C & 17 & 150.8 & 155.76 & 103.3 & 1 & 2.2 & 3.40 & 154.5 & 0 & 0.0 & 0.00 & NA & 18 & 153.0 & 159.16 & 104.0 \\
\hline & U1317D & 0 & 0.0 & 0.00 & NA & 0 & 0.0 & 0.00 & NA & 18 & 160.0 & 101.52 & 63.5 & 18 & 160.0 & 101.52 & 63.5 \\
\hline & U1317E & 18 & 158.6 & 163.48 & 103.1 & 0 & 0.0 & 0.00 & NA & 0 & 0.0 & 0.00 & NA & 18 & 158.6 & 163.48 & 103.1 \\
\hline \multicolumn{2}{|c|}{ Site U1317 totals: } & 67 & 585.4 & 593.6 & 101.4 & 4 & 13.2 & 14.7 & 111.2 & 18 & 160.0 & 101.5 & 63.5 & 89 & 758.6 & 709.8 & 93.6 \\
\hline \multirow[t]{3}{*}{ PORC-02A } & U1318A & 15 & 142.2 & 128.51 & 90.4 & 0 & 0.0 & 0.00 & NA & 0 & 0.0 & 0.00 & NA & 15 & 142.2 & 128.51 & 90.4 \\
\hline & U1318B & 14 & 128.5 & 121.22 & 94.3 & 13 & 116.1 & 92.26 & 79.5 & 0 & 0.0 & 0.00 & NA & 27 & 244.6 & 213.48 & 87.3 \\
\hline & U1318C & 7 & 58.6 & 54.61 & 93.2 & 3 & 28.8 & 29.54 & 102.6 & 0 & 0.0 & 0.00 & NA & 10 & 87.4 & 84.15 & 96.3 \\
\hline \multirow{2}{*}{\multicolumn{2}{|c|}{$\begin{array}{l}\text { Site U1318 totals: } \\
\text { Expedition totals: }\end{array}$}} & 36 & 329.3 & 304.3 & 92.4 & 16 & 144.9 & 121.8 & 84.1 & 0 & 0.0 & 0.0 & NA & 52 & 474.2 & 426.14 & 89.9 \\
\hline & & 119 & 1040.5 & 1022.52 & 98.3 & 33 & 225.8 & 190.73 & 84.5 & 29 & 263.1 & 171.67 & 65.2 & 181 & 1529.4 & 1384.92 & 90.6 \\
\hline
\end{tabular}

Notes: $N=$ number of cores, $\mathrm{NA}=$ not applicable 